Prepared in cooperation with the West Dakota Water Development District, South Dakota Department of Environment and Natural Resources, and Lawrence County

\title{
Microgravity Methods for Characterization of Groundwater- Storage Changes and Aquifer Properties in the Karstic Madison Aquifer in the Black Hills of South Dakota, 2009-12
}

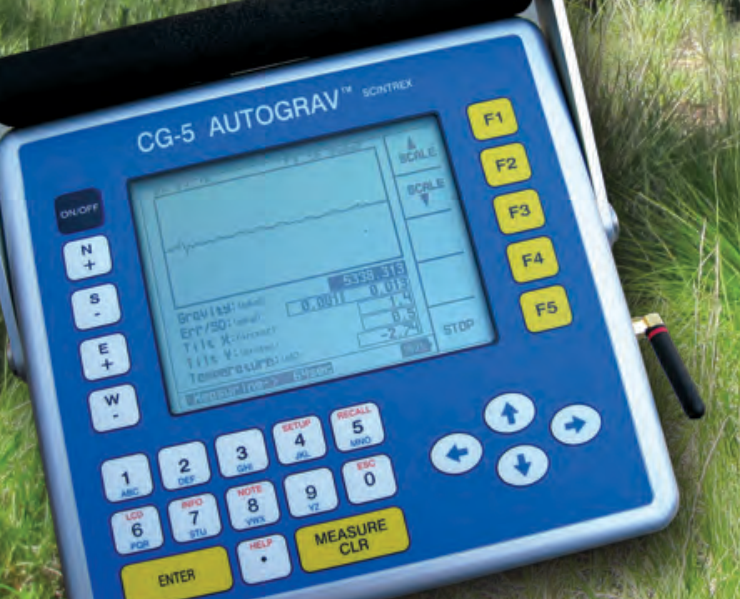

Scientific Investigations Report 2012-5158 
Front cover. Microgravity measurement at a gravity station in Spring Canyon with an outcrop of the Madison Limestone in the background. An inset of the of the measurement screen of the CG-5 relative gravimeter is shown in the lower left corner. This photograph was taken in the summer of 2012 by Jonathan McKaskey.

Back cover. Upper left: Measurement with the absolute gravimeter at a base station in the Doty focus area, S. Dak. Photograph by Jeff Kennedy.

Upper center: Leveling the lower unit of the absolute gravimeter at a base station in the Doty focus area, S. Dak. Photograph by Karl Koth.

Upper right: Measurement with the relative gravimeter at an absolute-gravity station on an outcrop of Precambrian rocks. Photograph by Jonathan McKaskey.

Lower left: Relative-gravity measurement in the Doty focus area, S. Dak., with a future scientist in the background. Photograph by Jonathan McKaskey. Lower right: Absolute-gravity measurement at a station located on top of Terry Peak in the northern Black Hills. 


\section{Microgravity Methods for Characterization of Groundwater-Storage Changes and Aquifer Properties in the Karstic Madison Aquifer in the Black Hills of South Dakota, 2009-12}

By Karl R. Koth and Andrew J. Long

Prepared in cooperation with the West Dakota Water Development District, South Dakota Department of Environment and Natural Resources, and Lawrence County

Scientific Investigations Report 2012-5158 


\title{
U.S. Department of the Interior \\ KEN SALAZAR, Secretary \\ U.S. Geological Survey \\ Marcia K. McNutt, Director
}

\author{
U.S. Geological Survey, Reston, Virginia: 2012
}

For more information on the USGS - the Federal source for science about the Earth, its natural and living resources, natural hazards, and the environment, visit http://www.usgs.gov or call 1-888-ASK-USGS.

For an overview of USGS information products, including maps, imagery, and publications, visit http://www.usgs.gov/pubprod

To order this and other USGS information products, visit http://store.usgs.gov

Any use of trade, firm, or product names is for descriptive purposes only and does not imply endorsement by the U.S. Government.

Although this information product, for the most part, is in the public domain, it also may contain copyrighted materials as noted in the text. Permission to reproduce copyrighted items must be secured from the copyright owner.

Suggested citation:

Koth, K.R., and Long, A.J., 2012, Microgravity methods for characterization of groundwater-storage changes and aquifer properties in the karstic Madison aquifer in the Black Hills of South Dakota, 2009-12: U.S. Geological Survey Scientific Investigations Report 2012-5158, 22 p. 


\section{Acknowledgments}

This study was conducted by the U.S. Geological Survey (USGS) South Dakota Water Science Center in Rapid City, South Dakota, in cooperation with the West Dakota Water Development District, South Dakota Department of Environment and Natural Resources, and Lawrence County. Special thanks are extended to Robert Carruth, Donald Pool, and Jeff Kennedy from the USGS Arizona Water Science Center for providing valuable advice in site installation and gravity-survey procedures and also for making the A-10 absolute gravimeter measurements. We are indebted to Mike Webring, Chad Ailes, and Ben Drenth of the USGS Crustal Geophysics and Geochemistry Science Center in Denver, Colorado, for maintaining the CG-5 relative gravimeter and for their help in developing a better understanding of gravimeters and gravity measurement techniques. 


\section{Contents}

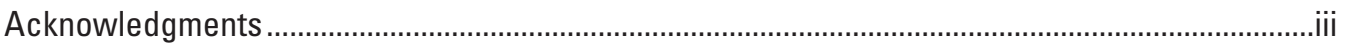

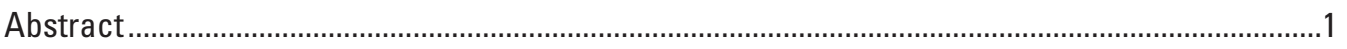

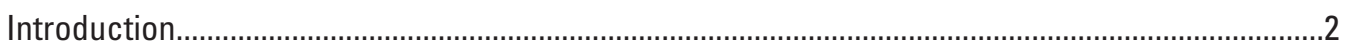

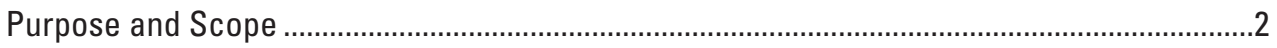

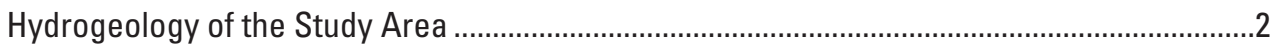

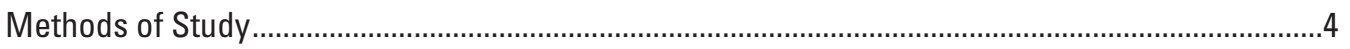

Absolute and Relative Gravity Measurements ...........................................................................4

Methods for Determining Groundwater-Storage Change and Effective Porosity ....................5

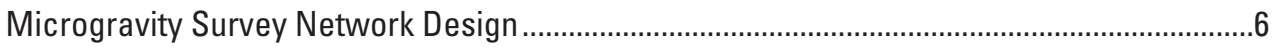

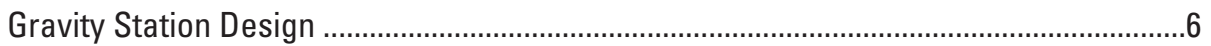

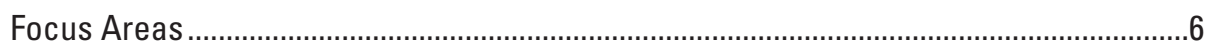

Microgravity Measurement Methods ..............................................................................

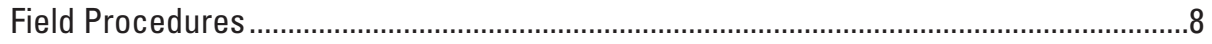

Sources of Error ..................................................................................................................

Characterization of Groundwater-Storage Changes and Aquifer Properties ..................................10

Spring Canyon Focus Area ............................................................................................. 10

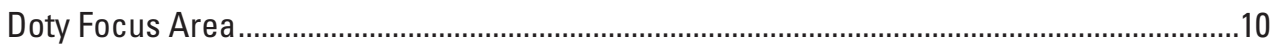

Limestone Plateau Focus Area ..................................................................................................15

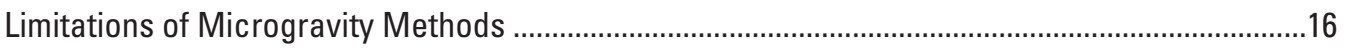

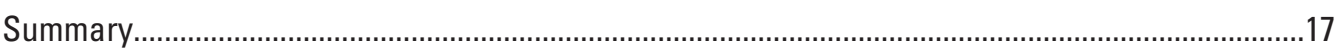

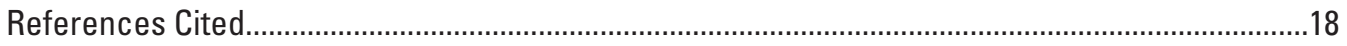

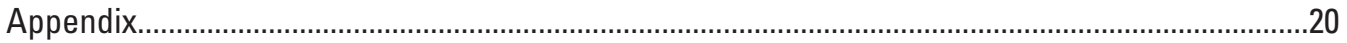

\section{Figures}

1. Map showing study area, geologic units, and data collection sites ................................

2. Map showing Doty focus area showing gravity stations and observation wells ..............7

3. Graph showing groundwater-storage change determined from gravity data at station TEU plotted with the hydrograph for observation well RG-Mdsn (PE-86A) and streamflow for streamgage 06407500 from January 2010 to October 2011 ..............11

4. Graph showing groundwater-storage change determined from gravity data for group 2 stations in the Doty focus area plotted with the hydrograph for observation well Doty-Mdsn (PE-95C). 
5. Conceptual plot of change in water-table altitude and groundwater-storage change with divisions where the balance of inflow to outflow in the unsaturated zone changes .

6. Diagram showing effective porosity estimates for Madison aquifer beneath station MN04 for vertical sections a-d determined for three different time periods.

7. Graph showing groundwater-storage change determined from gravity data for group 1 stations in the Doty focus area plotted with the hydrograph for observation well Doty-Mdsn (PE-95C)

8. Water-level hydrograph for lake in Brooks Cave from 1988 to 1998

9. Graph showing groundwater-storage change determined from gravity data for station 027 plotted with the hydrograph for observation well Chyn-Xing-Mdsn (LA-95B)

1-1. Graph showing relative-gravity measurements made at the U.S. Geological Survey South Dakota Water Science Center in Rapid City, South Dakota, on September 19, 2011, plotted with a fitted sixth-order polynomial

1-2. Graphs showing relative-gravity measurements for a survey conducted on June 9, 2011, at stations MN04, MN05, MN06, and MD01 plotted with a fitted fifth-order polynomial.

\section{Conversion Factors}

\begin{tabular}{|c|c|c|}
\hline Multiply & By & To obtain \\
\hline \multicolumn{3}{|c|}{ Length } \\
\hline inch (in.) & 2.54 & centimeter $(\mathrm{cm})$ \\
\hline inch (in.) & 25.4 & millimeter (mm) \\
\hline foot (ft) & 0.3048 & meter $(\mathrm{m})$ \\
\hline mile (mi) & 1.609 & kilometer (km) \\
\hline \multicolumn{3}{|c|}{ Flow rate } \\
\hline cubic foot per second $\left(\mathrm{ft}^{3} / \mathrm{s}\right)$ & 0.02832 & cubic meter per second $\left(\mathrm{m}^{3} / \mathrm{s}\right)$ \\
\hline \multicolumn{3}{|c|}{ Acceleration } \\
\hline Galileo (Gal) & 1 & centimeter per second squared $\left(\mathrm{cm} / \mathrm{s}^{2}\right)$ \\
\hline
\end{tabular}

Vertical coordinate information is referenced to the North American Vertical Datum of 1988 (NAVD 88).

Horizontal coordinate information is referenced to the North American Datum of 1983 (NAD 83).

Altitude, as used in this report, refers to distance above the vertical datum. 


\title{
Symbols, Units of Measurement, Abbreviations, and Acronyms
}

\author{
$b \quad$ thickness of Bouguer slab \\ $g \quad$ accelerative force of gravity \\ G universal gravitational constant \\ $\Delta g \quad$ change in gravitational potential \\ $\Delta h \quad$ change in water-table altitude \\ M mass of the Earth \\ $n \quad$ number of averaged relative-gravity measurements \\ $O_{p} \quad$ order of polynomial \\ $r \quad$ distance to the Earth's center of mass \\ $\Delta S \quad$ change in groundwater storage \\ $\varphi \quad$ effective porosity \\ $\rho_{\mathrm{w}} \quad$ density of water \\ $\Delta \rho_{\mathrm{rw}} \quad$ change in density of the rock and water slab \\ $>\quad$ greater than \\ $\pm \quad$ plus or minus \\ $\mu \mathrm{Gal} \quad$ microgal \\ SDDENR South Dakota Department of Environment and Natural Resources
}




\title{
Microgravity Methods for Characterization of Groundwater-Storage Changes and Aquifer Properties in the Karstic Madison Aquifer in the Black Hills of South Dakota, 2009-12
}

\author{
By Karl R. Koth and Andrew J. Long
}

\section{Abstract}

A study of groundwater storage in the karstic Madison aquifer in the Black Hills of South Dakota using microgravity methods was conducted by the U.S. Geological Survey in cooperation with West Dakota Water Development District, South Dakota Department of Environment and Natural Resources, and Lawrence County. Microgravity measurements from 2009 to 2012 were used to investigate groundwaterstorage changes and effective porosity in unconfined areas of the Madison aquifer. Time-lapse microgravity surveys that use portable high-sensitivity absolute and relative gravimeters indicated temporal-gravity changes as a result of changing groundwater mass. These extremely precise measurements of gravity required characterization and removal of internal instrumental and external environmental effects on gravity from the raw data. The corrected data allowed groundwaterstorage volume to be quantified with an accuracy of about plus or minus 0.5 foot of water per unit area of aquifer. Quantification of groundwater-storage change, coupled with water-level data from observation wells located near the focus areas, also was used to calculate the effective porosity at specific altitudes directly beneath gravity stations.

Gravity stations were established on bedrock outcrops in three separate focus areas for this study. The first area, the Spring Canyon focus area, is located to the south of Rapid City with one gravity station on the rim of Spring Canyon near the area where Spring Creek sinks into the Madison aquifer. The second area, the Doty focus area, is located on outcrops of the Madison Limestone and Minnelusa Formation to the northwest of Rapid City, and consists of nine gravity stations. The third area, the Limestone Plateau focus area, consists of a single gravity station in the northwestern Black Hills located on an outcrop of the Madison Limestone. An absolute-gravity station, used to tie relative-gravity survey data together, was established on a relatively impermeable bedrock outcrop to minimize groundwater-storage change at the reference location.

Data from the three focus areas allow for interpretation of groundwater-storage characteristics using microgravity measurements. Gravity measurements, together with waterlevel data from an observation well located 2 miles from the Spring Canyon focus area and measured streamflow in Spring Creek, provided evidence that rapid groundwater-storage change, responding to changes in sinking streamflow over the recharge area of the aquifer, occurred in the Madison aquifer directly beneath the gravity station at Spring Canyon. This phenomenon likely was a result of groundwater movement through caverns, conduits, and fractures, which are common in karst aquifers. Spatially and temporally separated microgravity data for the Doty focus area indicated horizontal and vertical heterogeneity of effective porosity for the Madison aquifer. One such example of this was indicated by water-level measurements at an observation well and gravity measurements at four gravity stations in the southeastern part of the Doty area, which were used to estimate effective porosity values ranging from greater than 0 to 0.18 . A decrease in groundwater storage determined by microgravity measurements during the spring recharge period for five upgradient stations in the Doty focus area indicated the possibility of rapid release and downgradient cascading of perched groundwater. Evidence for similar phenomena was documented for Wind Cave and Brooks Cave in the Black Hills. Absolute-gravity measurements at the Limestone Plateau focus area confirmed the relation between water levels in an observation well and changes in groundwater storage. Comparison of these gravity measurements with water levels in a nearby observation well resulted in an effective porosity estimate of 0.02 for the Madison aquifer beneath the gravity station. 


\section{Introduction}

Microgravity methods were applied to the Madison aquifer in the Black Hills of western South Dakota as an exploratory pilot study to evaluate the potential utility of these methods for advancing the knowledge of groundwater-storage change, groundwater flow, and effective porosity in this karstic aquifer. Changes in the Earth's gravitational field can be used to infer changes in groundwater storage caused by a change in mass from the addition or subtraction of groundwater. One factor that affects the gravitational force on the Earth's surface is the density of the underlying mass. The most common cause of density change over time is a change in groundwater storage or groundwater mass change beneath a particular location, which can be quantified by measuring temporal changes in the gravitational force (Damiata and Lee, 2006; Christiansen and others, 2011). The gravitational force may be measured with portable gravimeters.

Microgravity methods have been used in several applications to monitor changes in groundwater storage (Pool and Schmidt, 1997; Blainey and others, 2007; Pool and Anderson, 2008; Jacob and others, 2010). These investigations of groundwater-storage change and specific yield using temporal-gravity methods were helpful in planning the study methods for the Madison aquifer and gave insight to data analysis techniques and considerations. Blainey and others (2007) estimated specific yield, storage change, and hydraulic conductivity using simulated data with a 1-microgal $(\mu \mathrm{Gal})$ noise level. Other studies of unconfined alluvial aquifers, such as those in Pool and Schmidt (1997) and Pool and Anderson (2008), determined temporal gravity changes using gravimeters. Pool and Schmidt (1997) used only relative gravimeters, whereas Pool and Anderson (2008) used absolute and relative gravimeters. The use of the highly portable CG-5 relative gravimeter allowed for gravity surveys that included a larger number of gravity stations than surveys using only an absolute gravimeter, which requires more time to deploy and make a measurement than a relative gravimeter.

Aside from the study conducted by Jacob and others (2010) for the karstic Durzon aquifer in France, few microgravity studies have been documented for karstic or fractured aquifers such as those in the Black Hills. Because of the challenges related to characterizing these highly heterogeneous aquifers, microgravity methods that have not been applied may provide useful information that was not available using only data obtained from observation wells. Installing deep observation wells in competent bedrock is costly, whereas microgravity methods can be used to monitor changes in groundwater storage in areas where observation wells cannot be installed because of cost or access. Observation wells and microgravity monitoring provide different but related information about groundwater. Observation wells monitor changes in hydraulic head, which can be done continuously with recorders (Cunningham and Schalk, 2011). Pumping tests using these observation wells can be used to infer aquifer properties such as transmissivity, specific yield, and effective porosity (Heath, 2004). Microgravity measurements can be used to monitor changes in groundwater-storage volume, or mass. Coupling groundwater-storage change determined from microgravity measurements with changes in hydraulic head at observation wells permits estimates of effective porosity. Quantification of groundwater storage based on groundwater levels alone is difficult because effective porosity is largely unknown. Therefore, microgravity methods provide information that cannot be obtained by other methods. For example, these microgravity methods were used to estimate the effective porosity at different altitudes in the Madison aquifer beneath a gravity station.

The U.S. Geological Survey in cooperation with the West Dakota Water Development District, South Dakota Department of Environment and Natural Resources, and Lawrence County conducted a pilot study from 2009 to 2012 to evaluate the potential utility of microgravity methods for the Madison aquifer in the Black Hills of western South Dakota. Objectives of this study were to (1) measure and assess the characteristics of groundwater-storage changes in unconfined areas of the Madison aquifer; (2) determine effective porosity for areas where observation wells exist; and (3) assess the horizontal and vertical heterogeneity of effective porosity at selected locations.

\section{Purpose and Scope}

The purpose of this report is to document the results of the application of microgravity methods and provide analyses of storage changes and aquifer properties based on microgravity measurements made from 2009 to 2012. Although the primary focus of this report is the Madison aquifer, analysis of microgravity data for the overlying Minnelusa aquifer also is included. Estimates of effective porosity and the heterogeneity thereof provided in this report are useful for watermanagement considerations and additional investigations, such as groundwater modeling. Methods to monitor groundwaterstorage changes directly and without observation wells are described as well as phenomena unique to karst aquifers that were detected by microgravity methods. This report provides useful information about microgravity measurement methods and inherent challenges in analyzing high-precision measurements of Earth's gravitational field. Field procedures and methods of analysis for microgravity data are described, which may provide a guide for future microgravity studies.

\section{Hydrogeology of the Study Area}

The study area is located in the Black Hills of western South Dakota. The Black Hills are a doubly-plunging fold structure with Paleozoic-age sedimentary formations dipping radially outward on the flanks and overlying Precambrian-age rocks (fig. 1). Detailed geologic and hydrogeologic descriptions of the region can be found in Gries and Martin (1981), Strobel and others (1999), and Redden and DeWitt (2008). 


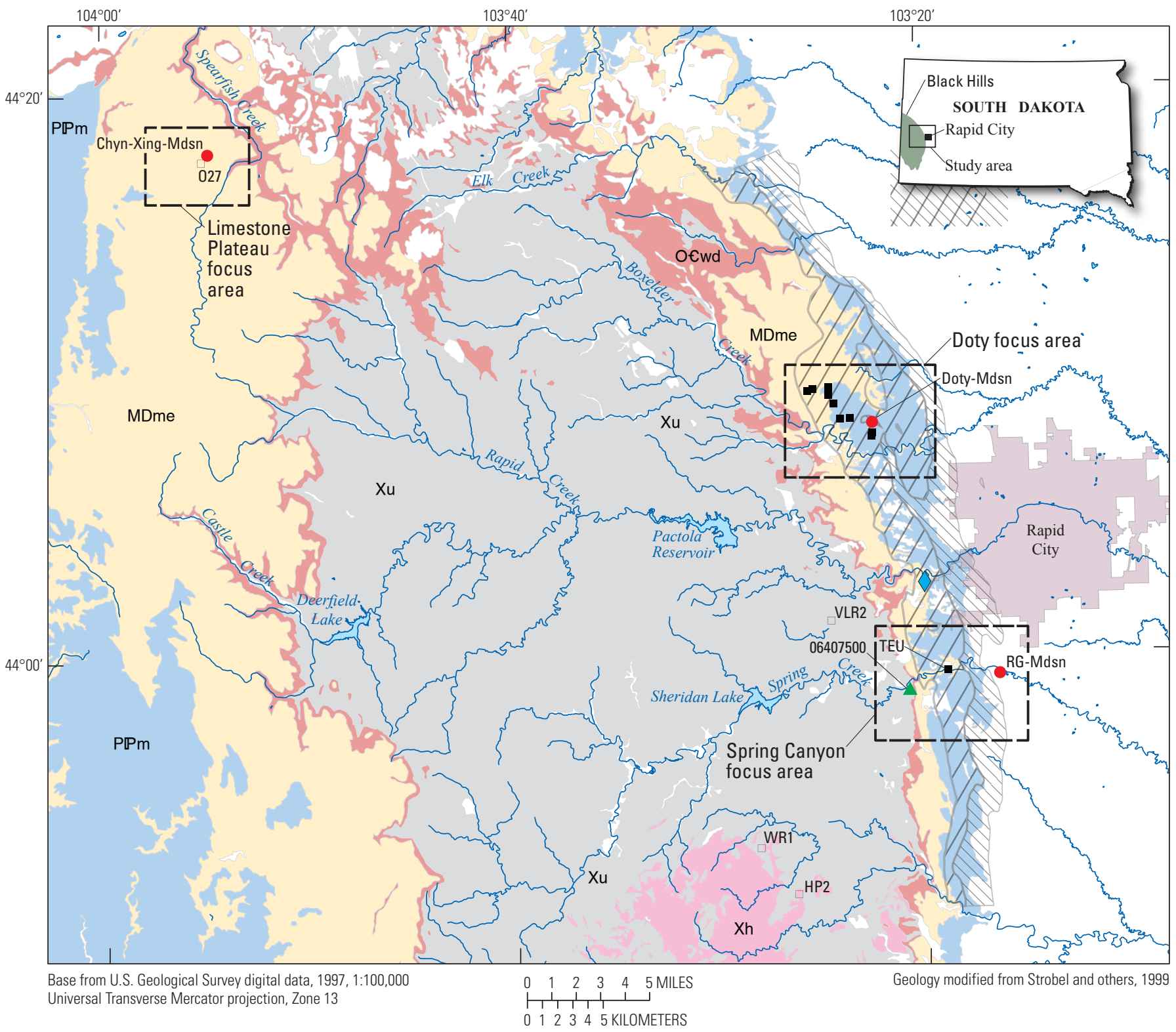

EXPLANATION

Geologic units

PPm Minnelusa Formation (Lower Permian and Pennsylvanian)

MDme Madison (Pahasapa) Limestone (Lower Mississippian) and Englewood Limestone (Lower Mississippian and Upper Devonian)

OEwd Whitewood Limestone (Upper Ordovician), Winnepeg Formation (Middle Ordovician), and Deadwood Formation (Lower Ordovician and Cambrian)

\begin{tabular}{|c|}
\hline $\mathrm{Xh}$ \\
\hline $\mathrm{Xu}$
\end{tabular}

Harney Peak Granite (Early Proterozoic)

Precambrian rocks, undifferentiated (Early Proterozoic and Late Archean)

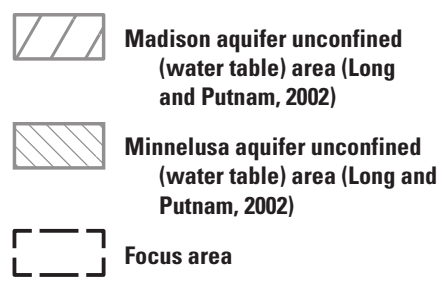

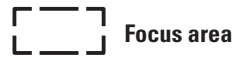

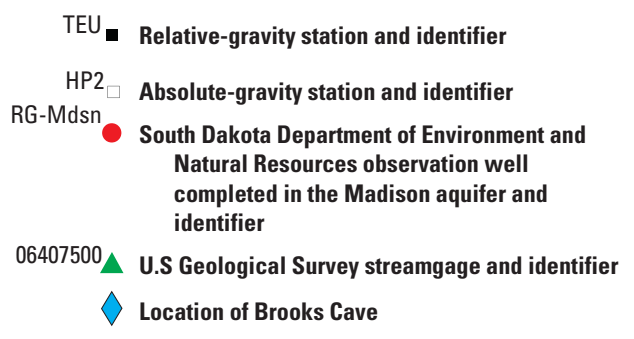

Figure 1. Study area, geologic units, and data collection sites. 
The primary focus of this study is the Madison aquifer, but the overlying Minnelusa aquifer also is included in the analysis.

The Minnelusa aquifer is contained within the Pennsylvanian- and Permian-aged Minnelusa Formation. The Minnelusa Formation ranges from 375 to 1,175 feet (ft) thick in the Black Hills (Carter and others, 2003). Two different lithologic regimes divide the Minnelusa Formation into upper and lower units: the upper unit contains thick sandstone with thin limestone, dolomite and mudstone, and the lower unit has less sandstone and more shale, limestone, and dolomite (Bowles and Braddock, 1963). Siltstone, gypsum, and anhydrite also may be present in the lower unit.

Underlying the Minnelusa aquifer is the Madison aquifer, which is contained within the Mississippian-age Madison Limestone, locally named the Pahasapa Limestone, which is a massive, slabby limestone that contains both dolostone and limestone and has a large secondary porosity component consisting of fractures and solution openings. This porosity component commonly is contained in the upper 100 to $200 \mathrm{ft}$ of the Madison Limestone, which is a well-developed karst aquifer with large networks of groundwater conduits and pore spaces that result from dissolution of carbonate rocks (Greene, 1993). The Madison Limestone ranges from less than 200 to $1,000 \mathrm{ft}$ thick in the Black Hills region (Carter and others, 2003).

Underlying the Madison Limestone are the Devonianand Mississippian-age Englewood Limestone and the Cambrian- and Ordovician-age Deadwood Formation. The Englewood Limestone is relatively thin, ranging from 0 to $60 \mathrm{ft}$ thick, and may be considered as part of the Madison Limestone (Gries and Martin, 1981). In the northern part of the study area, the Ordovician-age Whitewood Limestone and Winnipeg Formation are present between the Englewood Limestone and Deadwood Formation. Hydrogeologically, these formations may be considered part of the underlying Deadwood Formation. The Deadwood Formation is 0 to $500 \mathrm{ft}$ thick, and is the oldest and least porous of the sedimentary rocks described in this report (Carter and others, 2003). Underlying the Whitewood Limestone, Winnipeg Formation, and Deadwood Formation are Precambrian-age metamorphic and igneous rocks.

Recharge to the Madison and Minnelusa aquifers occurs as infiltration of direct precipitation and sinking streams (streamflow recharge) on exposed areas of these aquifers. Recharge primarily occurs during the wettest parts of the year from March through July. Groundwater flow generally is radially outward from recharge areas and in a down-dip direction. The water table of a karst aquifer, such as the Madison aquifer, may not be a smooth surface typical of other aquifers but can be better characterized as multiple water surfaces at different altitudes in numerous caves or other solution openings. As sinking streams or precipitation infiltrates the aquifer, these openings can overfill and water can flow into adjacent openings at lower altitudes, resulting in a procession of water cascading from one opening to another in a downgradient direction (Long and others, 2012). Perched water also exists in caves in karst aquifers.

\section{Methods of Study}

This section includes a brief introduction to the measurement of gravity, or gravimetry. The primary objective of the first part of this section is to describe the utility of absolute and relative gravimeters in groundwater-storage monitoring and to provide a short derivation of the theory of gravity measurement. The design of the gravity station network and the methods for microgravity measurements and analyses specific to this study are described in the second part of this section.

\section{Absolute and Relative Gravity Measurements}

The Earth's gravitational field varies across the surface and is affected by altitude and the density of the underlying rock and groundwater. Two types of gravimeters exist: absolute and relative (Pool and Anderson, 2008). A measurement made with an absolute gravimeter indicates the absolute accelerative force of gravity at the measurement location, which is referred to hereafter as $g$. The unit of measure for $g$ is the Gal, equal to 1 centimeter per second squared $\left(\mathrm{cm} / \mathrm{s}^{2}\right)$. High-precision gravity methods required for groundwater applications are referred to as microgravity methods, and thus $g$ is reported in microgals $\left(\mu \mathrm{Gal}\right.$, or $\left.10^{-6} \mathrm{Gal}\right)$ in this report. A relative gravimeter cannot be calibrated to measure $g$ directly because of uncertain long-term instrument drift. Relativegravity measurements made at two stations, however, indicate the difference in $g$ between these stations. Therefore, one use of relative-gravity surveys is to measure spatial differences in the Earth's gravitational field. Measurements made during a relative-gravity survey can be converted to $g$ values if one of the relative-gravity measurements is made at a station where $g$ has been measured by an absolute gravimeter. A relative gravimeter is more portable than an absolute gravimeter and therefore was the primary gravimeter used in this study. All relative-gravity measurements were converted to $g$ values, and by doing so the temporal change in the gravitational force at each station between surveys was quantified and compared over the entire period of the study.

Measurements of $g$ were made with a Micro-g Lacoste, Inc., A-10 absolute gravimeter. This meter measures the acceleration of a free-falling corner cube test mass contained inside a drag-free vacuum chamber. A laser interferometer measures the position of the falling mass, and a rubidium oscillator provides a time reference. At an optimal measurement site, the A-10 absolute gravimeter measures $g$ with an accuracy of plus or minus $( \pm) 10 \mu \mathrm{Gal}$ (http://www.microglacoste.com/a10.php). This uncertainty may increase depending on site conditions, that is, the uncertainty may be greater than $\pm 10 \mu \mathrm{Gal}$. 
Relative-gravity measurements were made at stations over unconfined parts of the Madison and Minnelusa aquifers using the Scintrex CG-5 Autograv. The CG-5 relative gravimeter measures relative differences in gravitational attraction using a fused-quartz elastic system. This system operates by balancing the elongation of a fused-quartz proof mass with an electrostatic restoring force, where the restoring force is equal to the relative gravity value. The displacement of the proof mass is measured using a capacitive displacement transducer. The displacement transducer signal drives a feedback circuit that controls the magnitude of the electrostatic restoring force. The Scintrex CG-5 gravimeter has a measurement resolution of $1 \mu \mathrm{Gal}$ with an accuracy of $\pm 5 \mu \mathrm{Gal}$ (http:// scintrexltd.com/internal.php? storeCategoryID $=1 \&$ subcatID $=$ $9 \&$ s_page $=$ Gravity $\# C G-5)$.

\section{Methods for Determining Groundwater-Storage Change and Effective Porosity}

Microgravity methods were used to determine temporal changes in groundwater mass. It was assumed that the only mass changes, and therefore, changes in $g$, occurring beneath measurement stations resulted from changes in groundwater storage. Because little groundwater-storage change occurs in confined aquifers, all estimated groundwater-storage changes were assumed to occur only in unconfined aquifers, generally the uppermost aquifer beneath a measurement station. A brief explanation of the theory of microgravity analysis and a derivation of applicable equations follow (Pool and Eychaner, 1995).

The generalized form of Newton's Law of Gravitation states that the acceleration resulting from the Earth's mass is proportional to this mass and inversely proportional to the square of the distance to the center of mass:

$$
g=G M / r^{2},
$$

where

$$
\begin{aligned}
& g \quad \text { is the accelerative force of the Earth's } \\
& \text { gravitational field, } \\
& G \text { is the universal gravitational constant, } \\
& M \quad \text { is the mass of the Earth, and } \\
& r \quad \text { is the distance to the Earth's center of mass. }
\end{aligned}
$$

A one-dimensional approximation of Newton's law may be made by assuming the lateral extent of the fluctuating groundwater mass is much larger than the vertical distance to the groundwater mass. In this application, the changing groundwater mass occurs in saturated and unsaturated zones and is assumed to be in the form of a slab of infinite extent. Because this slab contains rock and water, its density changes as groundwater-storage changes. This approximation is referred to as the Bouguer slab equation (Telford and others, 1990):

$$
\Delta g=2 \pi G \Delta \rho_{\mathrm{rw}} b,
$$

where

$$
\begin{array}{cl}
\Delta g & \begin{array}{c}
\text { is the change in the gravitational potential } \\
\text { resulting from a change in groundwater } \\
\text { storage mass, }
\end{array} \\
\Delta \rho_{\mathrm{rw}} & \begin{array}{l}
\text { is the change in density of the rock and water } \\
\text { slab, and }
\end{array} \\
b & \text { is the thickness of the slab. }
\end{array}
$$

A beneficial consequence of using the Bouguer slab equation is that $\Delta g$ is independent of the distance to the groundwater table because equation 2 contains no distance term.

In this derivation, the thickness of the Bouguer slab $(b)$ is assumed to be the entire thickness of the volume in which groundwater-storage change occurs. For the special case in which the groundwater-storage change in the unsaturated zone is zero, $b$ is equal to the change in water-table altitude $\Delta h$, and the change in density then is calculated as the effective porosity $(\varphi)$ times the density of water $\rho_{\mathrm{w}}$ :

$$
\Delta \rho_{\mathrm{rw}}=\varphi \rho_{\mathrm{w}}
$$

Substituting equation 3 into equation 2 for the special case where $\Delta h$ equals $b$ and combining the constant parameters yields

$$
\Delta g=0.4192 \varphi \Delta h,
$$

where

$\Delta g \quad$ is the change in the gravitational potential in microgals,

$\varphi \quad$ is the effective porosity,

$\Delta h \quad$ is the change in water-table altitude in centimeters, and

$$
\Delta g=12.77 \varphi \Delta h,
$$

where

$$
\begin{aligned}
& \Delta g \text { is the change in the gravitational potential in } \\
& \text { microgals, }
\end{aligned}
$$

Also for the special case of $\Delta h=b$, the effective porosity can be expressed as

$$
\varphi=\Delta S / \Delta h,
$$

where
$\varphi \quad$ is the effective porosity,
$\Delta S \quad$ is the groundwater-storage change expressed as the change in the vertical height of water in feet with no rock present, and $\Delta h \quad$ is the change in water-table altitude in feet. 
For example, for a $10-\mathrm{ft}$ increase in the water table in an aquifer with 10 percent effective porosity, $\Delta S$ would be equal to $1 \mathrm{ft}$, assuming that no mass change in the unsaturated zone occurred. Combining equations 5 and 6 yields

$$
\Delta S=\Delta g / 12.77
$$

Rearranging equation 5 yields the final equation for the effective porosity of an unconfined aquifer at the water table as a function of the change in gravitational potential $(\Delta g)$, in microgals, and water-level change $(\Delta h)$, in feet, for cases when $\Delta h=b$ :

$$
\varphi=\Delta g / 12.77 \Delta h
$$

\section{Microgravity Survey Network Design}

This section describes the general requirements for gravity station design. Detailed descriptions of the survey networks (focus areas) used in this study are also provided in the section.

\section{Gravity Station Design}

An absolute-gravity station on the Harney Peak Granite (station HP2; fig. 1) was established in 2009 and measured with the absolute gravimeter annually in the summers of 2009-11 and the spring of 2012. This location was selected because the granite has very low porosity. The measurements of $g$ at absolute-gravity station HP2 showed that values of $g$ at the station varied by a maximum of $21 \mu \mathrm{Gal}$ (2009-12), which is within $\pm 10.6 \mu \mathrm{Gal}$ of uncertainty in A-10 absolute gravimeter field measurements of $g$ at station HP2. These measurements are consistent with the assumption that there was little or no groundwater-storage change at this location. However, this station was not used for relative gravity surveys because the CG-5 relative gravimeter had odd drift that resulted in large uncertainties when measuring at station HP2. The drift in these surveys might have resulted from the very winding road that leads to station HP2 that caused abnormally high transportation drift in the relative gravimeter. A new absolute-gravity station, WR1, was established in 2012 along a straighter road crossing the Harney Peak Granite for use in future microgravity studies in the Black Hills area.

As a result of the large uncertainty in relative gravity surveys at station HP2, another absolute-gravity station, VLR2, was established on an outcrop of low-permeability Precambrian rocks with an access road (fig. 1). This location is at the top of a ridge of resistant rocks where precipitation forms in pools with little infiltration. Because of the apparent low permeability at this location, the subsurface was assumed to have little change in groundwater storage, and therefore, little change in the gravitational field. An important criterion restricting the selection of an absolute-gravity station location is that the station needs to be accessible by vehicle for measurements with the A-10 absolute gravimeter. Placement and orientation of the A-10 absolute gravimeter were recorded using paint markers, survey pins, and photographs in the field.

Relative-gravity station locations were selected on the basis of site stability, underlying geologic unit, and accessibility. Resistance to erosion and ground movement made bedrock outcrops a favorable platform on which to establish gravity stations. At station RCPC-4, where no bedrock was exposed, a concrete platform was constructed on top of an existing land-survey marker consisting of a 7 -ft deep concrete column, which extends below the frost line to ensure that frost heave does not perturb the station altitude (fig. 2). At most stations, three indentations each about 0.5 inch (in.) in diameter and 0.3 in. deep were drilled into the bedrock station platform and used to position the leveling tripod on which the $\mathrm{CG}-5$ relative gravimeter was placed during measurements. These positioning indentations maintained consistent orientation of the gravimeter and aided in leveling the instrument during measurements. Paint markers also were used to help identify and locate stations during field surveys and to indicate the direction that the gravimeter was oriented during measurements.

\section{Focus Areas}

Gravity stations were established in three separate focus areas for this study. The water table of the Madison aquifer was assumed to exist beneath all gravity stations, except absolute-gravity stations VLR2, HP2, and WR1 (fig. 1). All measureable groundwater-storage change was assumed to occur in unconfined areas of the Madison aquifer, with the addition of the unsaturated zone of the Minnelusa aquifer in some areas. Underlying confined aquifers were assumed to have negligible groundwater-storage change.

The survey network for the Spring Canyon focus area consists of one relative-gravity station on the rim of Spring Canyon (station TEU) and the absolute-gravity station VLR2 located 5 miles (mi) to the west (fig. 1). The South Dakota Department of Environment and Natural Resources (SDDENR) observation well RG-Mdsn, also called PE86A, is open to the Madison aquifer from 1,194 to 1,220 feet below the land surface and is located $2 \mathrm{mi}$ to the east of station TEU (U.S. Geological Survey, 2012). Recharge to the Madison and Minnelusa aquifers in this area primarily occurs as streamflow recharge from Spring Creek, which sinks into these aquifers at several locations where the stream crosses outcrop areas, with a maximum estimated rate of 21 cubic feet per second $\left(\mathrm{ft}^{3} / \mathrm{s}\right)$ into the Madison aquifer (Hortness and Driscoll, 1998; Long and Putnam, 2002). A streamgage for Spring Creek (streamgage 06407500; U.S. Geological Survey, 2012) is located upstream from where the stream sinks (fig. 1). Groundwater flow generally is to the east and northeast (Greene, 1993).

In the Doty focus area, located on the eastern side of the Black Hills (fig. 1), the sedimentary formations that make up the hydrogeologic units generally dip to the east (Redden and 


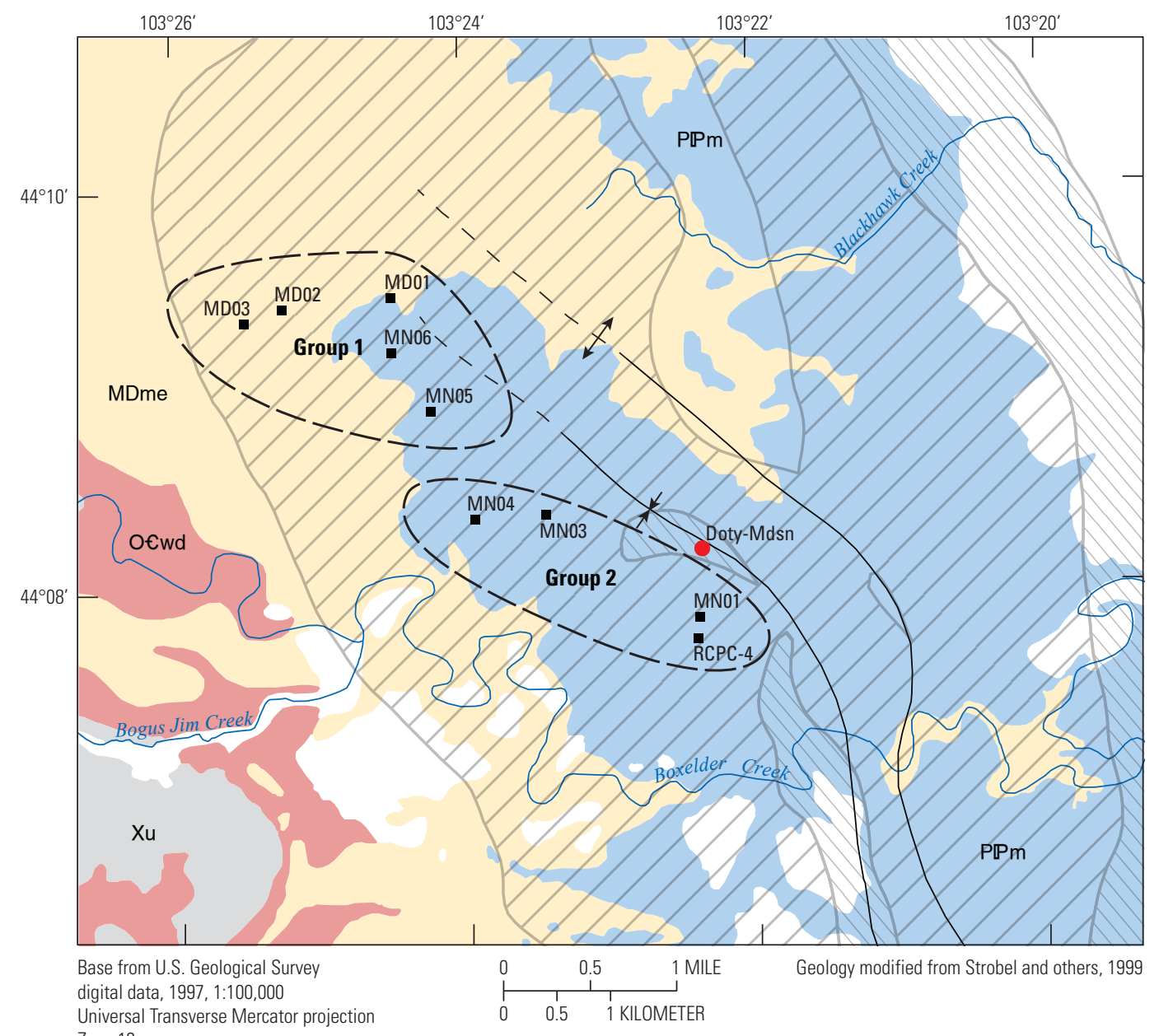

Universal Transverse Mercator projection Zone 13

\section{EXPLANATION}

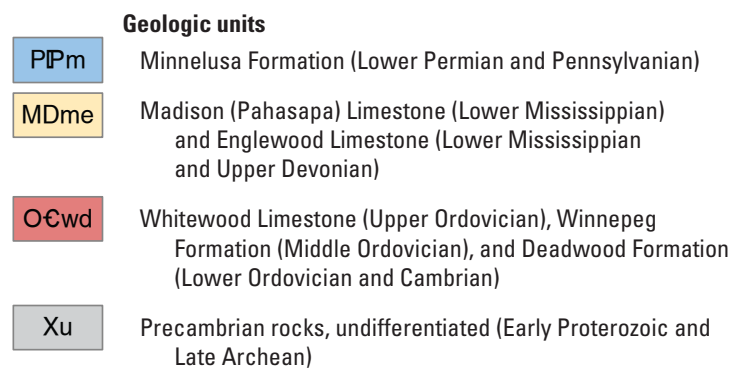

Madison aquifer unconfined (water table) area (Long and Putnam, 2002)

Minnelusa aquifer unconfined (water table) area (Long and Putnam, 2002)

Structural features

Anticline-Showing trace of axial

plane. Dashed where approximately located

Syncline-Showing trace of axial plane. Dashed where approximately located

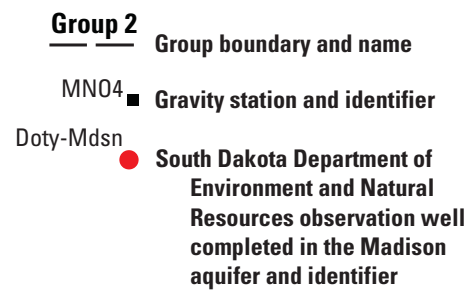

aquifer and identifier

Figure 2. Doty focus area showing gravity stations and observation wells.

DeWitt, 2008). Bisecting the Doty focus area from the northwest to the southeast is a fold couple consisting of a syncline and anticline (fig. 2). Evidence for a fold is apparent from the geologic contacts between the Madison Limestone and Minnelusa Formation. The presence of these structures is likely to affect the groundwater-storage characteristics of the area.

Drilling records for SDDENR observation well DotyMdsn, also called PE95C (fig. 2), indicate that the Minnelusa Formation is $335 \mathrm{ft}$ thick near the southeastern gravity stations in the Doty focus area. Because of the easterly dip of this formation in the area, the Minnelusa Formation diminishes in thickness to the west until it contacts the Madison outcrop, where the thickness of the Minnelusa Formation is zero. The Madison Limestone is about $455 \mathrm{ft}$ thick near the southeastern gravity stations in the Doty focus area and thins to the west in the outcrop area (Redden and DeWitt, 2008).

The survey network for the Doty focus area consists of nine relative-gravity stations located within outcrop areas of 
the Madison Limestone and Minnelusa Formation (fig. 2); the absolute-gravity station VLR2 is located 9 mi south of the Doty focus area (fig. 1). Relative-gravity stations were placed at approximately 0.5 -mi intervals overlying the water-table area of the Madison aquifer. The network of survey stations stretches over about $3.3 \mathrm{mi}$ trending from the northwest to the southeast. Observation well Doty-Mdsn is open to the Madison aquifer from 375 to 415 feet below the land surface (U.S. Geological Survey, 2012). Recharge in this area primarily occurs as infiltration of direct precipitation. Streamflow recharge also occurs about $1 \mathrm{mi}$ south of the gravity stations where Boxelder Creek sinks into the Madison and Minnelusa aquifers over a stretch of several miles as it crosses outcrops of the Madison and Minnelusa Formations (fig. 2).

Areas where the Madison and Minnelusa aquifers are unconfined and have water tables at the base of an unsaturated zone were estimated by Long and Putnam (2002; figs. 1 and 2). These authors also indicated that the boundaries of these zones change as water-table altitudes (or hydraulic heads as used for well hydrographs in this report) change because of the dip angles of the aquifers, and therefore, these boundaries are only approximations. A preferential southeasterly groundwater-flow path exists in the Madison aquifer approximately along the axis of the syncline shown in figure 2 (Long and Putnam, 2002). Group 1 gravity stations are located near the upgradient end of this flow path on or near the outcrop of the Madison Limestone (fig. 2). Group 2 gravity stations are located to the southeast of group 1 within or near this flow path and on the outcrop of the Minnelusa Formation (fig. 2).

The Limestone Plateau focus area in the northwestern part of the study area consists of one absolute-gravity station (O27) on an outcrop of the Madison Limestone (fig. 1). SDDENR observation well Chyn-Xing-Mdsn, also called LA-95B, is located $0.3 \mathrm{mi}$ northeast of gravity station $\mathrm{O} 27$ and is open to the Madison aquifer from 350 to 411 feet below the land surface (U.S. Geological Survey, 2012). Recharge in this area primarily occurs as infiltration of direct precipitation, and groundwater flow in the Madison aquifer generally is to the north (Greene and others, 1998).

\section{Microgravity Measurement Methods}

This section describes the methods used during microgravity field surveys and the errors induced by internal and external effects on the gravimeters. Solutions for removing errors and increasing measurement repeatability also are described.

\section{Field Procedures}

Field surveys conducted in the Doty and Spring Canyon focus areas consisted of one relative-gravity base station (the base station may be a relative or absolute-gravity station) and from one to five relative-gravity stations. For the Limestone
Plateau focus area, measurements of $g$ were made at absolutegravity station $\mathrm{O} 27$ with the A-10 gravimeter only. During a field survey with the CG-5 gravimeter, the first station measured was defined as the base station. The remaining relative-gravity stations were then measured to create a closed loop. The relative-survey loop, starting with the base station, was repeated in the same order from one to three times (a total of as many as four loops) during a field survey to ensure measurement repeatability and to help assess measurement accuracy. Each time a station was visited and measured is hereafter referred to as a station occupation. In most cases, the survey base station was occupied at least three times during the survey period to ensure measurement repeatability. Each gravity station occupation consisted of three 117 -second measurements during which data were continuously collected at a 6-hertz sample rate. These three measurements were averaged to obtain the tide-corrected gravity value for a given station occupation, which was later processed to remove instrument drift.

The CG- 5 gravimeter was transported in the passenger seat of a vehicle, open to the ambient air temperature, and buckled securely in place with a seatbelt. Special care was taken to avoid jarring the instrument while in transit or when moving the instrument from the vehicle to the survey station. Also, the instrument was lifted, turned, and set down slowly to minimize acceleration effects on the instrument. Whenever possible, a shelter was deployed over the gravity station during the entire survey period to shelter the gravimeter and rock outcrop from wind and sun exposure. For surveys including several gravity stations, the shelter was moved and deployed during measurements at all of the gravity stations. The CG-5 gravimeter also was allowed to stabilize for about 5 minutes at the survey station before gravity measurements were made. This procedure ensured the consistency of relative-gravity measurements and minimized measurement errors.

Absolute-gravity measurements were collected using the A-10 absolute gravimeter. A sport-utility vehicle supplied continuous power to the gravimeter and housed the data collection and processing instrument suite for the A-10 gravimeter. As described in the "Gravity Station Design" section of this report, the location of absolute-gravity station VLR2 was selected to be where groundwater-storage change was likely to be small in an area of low-porosity rock. Measurements were made at station VLR2 in July 2010 and June 2011 and indicated an increase of $17 \mu \mathrm{Gal}$ during this period, corresponding to an apparent increase in groundwater storage $(\Delta S)$ of $1.33 \mathrm{ft}$. Considering the potential measurement error of the A-10 gravimeter $( \pm 10 \mu \mathrm{Gal})$, this groundwater-storage change could be smaller or larger than this value. To account for this unexpected apparent change in storage, a linear interpolation between the two measurements at station VLR2 was used to estimate the $g$ value at this station for other measurement periods, assuming a linear change in groundwater level.

These interpolated $g$ values at station VLR2 were used to determine $g$ values at relative-gravity stations. This was done 
by making relative-gravity measurements at station VLR2 and a relative-gravity base station and subtracting the value of these two measurements to obtain the difference in gravity between the two stations. Measuring this difference with the CG-5 gravimeter is referred to as a connecting survey because this allows all measurements made during a relative-gravity survey to be converted to $g$ values. A connecting survey between the base station in a relative survey loop and the absolute-gravity station VLR2 was performed within 1 week of a relative-gravity survey. The field procedures during a connecting survey were conducted in the same manner as any other relative-gravity survey, except only two stations were measured. The difference in the gravitational field between the two stations in the connecting survey as measured by the $\mathrm{CG}-5$ gravimeter also is the difference in $g$ between the two stations. Therefore, this difference was subtracted from the interpolated $g$ value at station VLR2 for the date of the connecting survey to obtain the $g$ value at the relative-survey base station. For relative surveys occurring before or after the two absolute-gravity measurements at station VLR2 during July 2010 and June 2011, $g$ values for station VLR2 were extrapolated using the slope of the interpolated line between the two measurements at station VLR2.

\section{Sources of Error}

Gravitational attraction of the Sun and Moon cause harmonic deformation of the Earth's crust, which is referred to as the Earth tide. These transient tidal effects, with amplitudes of $100 \mu \mathrm{Gal}$ or more, appear in gravity data. The resulting ground motion (lithospheric flexure) is assumed to be continuous over the entire expanse of a survey area, which allows all measurement stations to be corrected by a single temporal function that represents this tidal motion for each field survey. The CG-5 gravimeter uses internal Earth-tide modeling software to calculate the theoretical Earth tide and remove it from the recorded measurement. Modeled Earth-tide corrections calculated by the CG- 5 gravimeter are accurate to less than $\pm 1 \mu \mathrm{Gal}$ and are a minimal source of error.

Other sources of measurement error include instrument drift and changes in barometric pressure, which may cause perturbations in gravity measurements that must be removed from the final data if the objective is to isolate the effects of groundwater-storage change $(\Delta S)$. The dominant component of internal instrument drift for the CG-5 gravimeter is approximately linear in nature and may be monitored and quantified during periods between relative-gravity surveys while the gravimeter is stationary. Changes in barometric pressure cause atmospheric pressure loading of the $\mathrm{CG}-5$ gravimeter, which has a small effect on measurements. Variations in barometric pressure cause changes of $\pm 0.3 \mu \mathrm{Gal}$ per hectoPascal (Jacob and others, 2010).
In addition to linear instrument drift in CG-5 gravimeter measurements, nonlinear instrument drift also exists, which may be induced by temperature variations in the gravimeter housing and tripod, voltage fluctuations, spring hysteresis, atmospheric pressure changes, and instrument transport (Torge, 1989). Sheltering the gravimeter and gravity stations prevented sun exposure from heating the outcrop, gravimeter, and tripod and causing tilts attributable to thermal expansion in the gravimeter housing and tripod. Wind induced error also was minimized by sheltering the gravimeter during measurements. Wind also may cause ground vibrations by causing trees to sway, which results in movement of the roots and surrounding ground. Therefore, gravity stations with trees in proximity were susceptible to interference from vibrations transmitted into the ground that were observed as an increase in standard deviation in the raw (unaveraged) data. The tripod was leveled with the front and right rear legs only so that the height of the left rear leg remained at a constant height throughout the survey. This eliminated error from instrument altitude changes, which are equal to about $7.5 \mu \mathrm{Gal}$ per inch of altitude change. Instrument height was recorded and compared at each base-station occupation to ensure consistent instrument height. Allowing the CG-5 gravimeter a short period to stabilize at the survey station after transportation considerably increased the repeatability of relative-gravity measurements. In the time between gravity surveys, the $\mathrm{CG}-5$ gravimeter was stored in a quiet location, remained on power, and leveled on the tripod to minimize spring hysteresis effects that occur when the sensor is out of level for extended periods.

Modeling techniques to correct for nonlinear drift as described by Torge (1989) include the fitting of polynomial or spline curves to measurement data for a gravity survey. A method based on these techniques was applied to measurements made with the CG-5 gravimeter for this study and is described in the appendix. The uncertainty determined by repeat measurements made with the $\mathrm{CG}-5$ gravimeter ranged from less than $1 \mu \mathrm{Gal}$ to $9 \mu \mathrm{Gal}$, corresponding to an uncertainty in $\Delta S$ of 0.25 to $8.5 \mathrm{in}$. The total uncertainty between two measurements was determined by summing, in quadrature, the individual uncertainties in each measurement. On average, the corrected data allowed groundwater-storage volume to be quantified with an accuracy of about plus or minus $0.5 \mathrm{ft}$ of water per unit area of aquifer. Linear and nonlinear drift corrections were not necessary for the A-10 absolute gravimeter because of the absence of measurement drift in free-fall gravimeters and internal correction for Earth tides, ocean loading (lithospheric flexure caused by ocean tides), polar motion (precession of the polar axis), and changes in barometric pressure. 


\section{Characterization of Groundwater- Storage Changes and Aquifer Properties}

This section presents the results of the microgravity measurements made during 2009-12 for this study. Quantitative and qualitative hydrologic analyses based on these measurements for the Spring Canyon, Doty, and Limestone Plateau focus areas are included in the section.

\section{Spring Canyon Focus Area}

Comparison of gravity data in the Spring Canyon focus area (fig. 1) collected in 2010 and 2011 at station TEU with water-level data for well RG-Mdsn and streamflow measurements for streamgage 06407500 indicate that groundwaterstorage change $(\Delta S)$ reflects temporal patterns in streamflow recharge to the Madison aquifer (fig. 3). Recharge from Spring Creek accounts for greater than 90 percent of the total recharge in this area (Long and Putnam, 2002). Groundwater storage at the Spring Canyon site between April 7, 2010, and September 25, 2011, varied by a maximum of $3.4 \mathrm{ft}$ of water per unit area of aquifer. The groundwater-storage change determined from gravity measurements is similar to the cycle of seasonal changes in streamflow recharge but different from changes in hydraulic head at the well RG-Mdsn, which is downgradient from the recharge area (fig. 3). Change in hydraulic head at well RG-Mdsn responds to upgradient groundwater-storage change in the Madison aquifer beneath station TEU in the streamflow recharge area. Figure 3 indicates that seasonal groundwater-storage changes at the streamflow recharge area have a damped response in the hydraulic head at well RG-Mdsn. Groundwater-storage change determined from gravity measurements in the recharge area correspond to increasing flows in Spring Creek in March through May. The estimated maximum streamflow recharge rate of $21 \mathrm{ft}^{3} / \mathrm{s}$ for the Madison aquifer (Hortness and Driscoll, 1998) is shown in figure 3. Streamflow in excess of this rate is assumed to flow downstream and not sink into the Madison aquifer. Rapid increases in groundwater storage occurred just after the streamflow exceeded the estimated maximum recharge rate and decreased soon after streamflow decreased below this rate. The quick response of groundwater-storage change to increasing streamflow recharge in the Spring Canyon focus area is consistent with the presence of karst features, such as caverns and conduits, in this area because these features allow rapid and focused recharge. Conduits then allow the rapid transport of this streamflow recharge away from the recharge area (Putnam and Long, 2007), which allows the groundwater-storage to decline rapidly after streamflow recharge declines. Unsaturated zone storage is assumed to be small in this area because these large conduits allow rapid transport of water from the sinking stream downward to the water table.
This rapid response of groundwater-storage change to streamflow recharge in the recharge area is not reflected by rapid hydraulic-head response at well RG-Mdsn (fig. 3). Hydraulic head measured in this well indicates a damped response compared with groundwater-storage change in the recharge area. This phenomenon is similar to quickly injecting water into a well (a slug test) and measuring the water level at the injection well and a proximal observation well. In this example, the observation well, which is analogous to well RG-Mdsn, will have a damped response in comparison to the injection well, which is analogous to the groundwater level at the stream sink. This difference in the hydraulic response between the recharge area and a downgradient area could not have been determined without gravity measurements at the recharge area because an observation well does not exist at that location.

\section{Doty Focus Area}

All gravity stations in the Doty focus area are located where the Madison aquifer water table is assumed to be unconfined (fig. 2). Beneath the group 1 gravity stations, the unsaturated zone of the Madison aquifer exists above the water table. At stations MN05 and MN06, which are located on Minnelusa Formation outcrop but near the Madison Limestone outcrop (fig. 2), a small thickness of the unsaturated zone of the Minnelusa Formation also overlies the Madison aquifer but is assumed to contribute little to the total groundwater-storage change for these stations. The unsaturated zone beneath the group 2 gravity stations, all of which are located on the Minnelusa Formation outcrop (fig. 2), consists of the unsaturated parts of the Madison and Minnelusa aquifers.

The calculation of effective porosity $(\varphi)$ in equation 8 applies when groundwater-storage change in the unsaturated zone is small and can be neglected, which occurs during periods when infiltration to the unsaturated zone is approximately equal to outflow. This equilibrium condition for the unsaturated zone is most likely to occur during the wettest part of the year because of frequent input of water, which percolates downward into the saturated part of the aquifer. This period begins after the start of the spring rains and ends before recharge decreases in mid to late summer.

Groundwater flow in the unsaturated zone is analogous to a leaky, sand-filled bucket. As water is slowly added to the top, the sand becomes partially saturated as water percolates downward and leaks out the bottom. If inflow and outflow balance, storage in the partially saturated sand is at equilibrium. It is uncertain how closely this equilibrium state is approximated in the unsaturated zone of the aquifer during wet seasons (March-July), but a comparison of gravity data to hydraulic heads at the observation well provides insight. Periods of relatively steady rise in the hydraulic head at well Doty-Mdsn were observed during wet seasons; increases in groundwater-storage as determined by gravity measurements were 

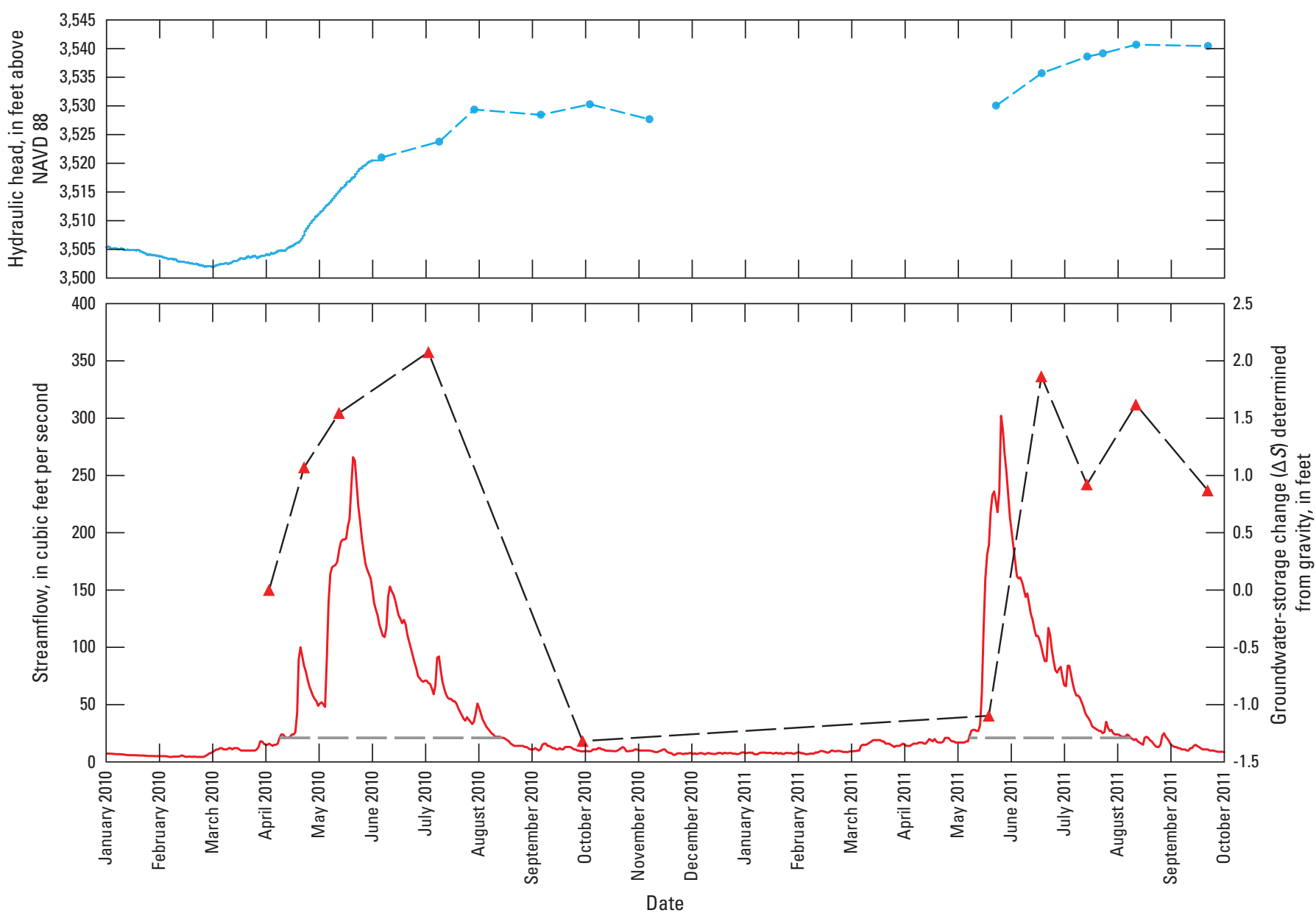

EXPLANATION
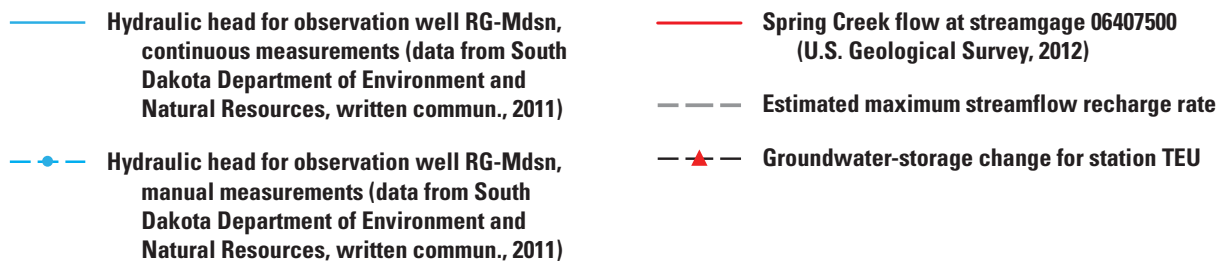

Figure 3. Groundwater-storage change $(\Delta S)$ determined from gravity data at station TEU plotted with the hydrograph for observation well RG-Mdsn (PE-86A) and streamflow for streamgage 06407500 from January 2010 to October 2011.

proportional to these hydraulic head increases for group 2 gravity stations (figs. 2 and 4).

When recharge subsides, water in the unsaturated zone continues to percolate downward, and a decline in groundwater-storage results. During the dry seasons (AugustFebruary), total groundwater-storage (saturated and unsaturated zones) declines by a larger amount per foot of waterlevel (hydraulic-head) change than the groundwater-storage increases during wet seasons because unsaturated-zone storage is declining during the dry seasons. Therefore, an equilibrium does not exist because inflow to the unsaturated zone is less than outflow unless storage in the unsaturated zone is zero, which is unlikely. This is illustrated conceptually in figure 5, where $\Delta S$ declines more quickly during periods of declining water levels than $\Delta S$ increases during periods of increasing water levels because of the decrease in unsaturated-zone storage. A near-equilibrium state is assumed to occur during periods of increasing water levels when the slope of the waterlevel change is nearly constant (inflow equals outflow; fig. 5). During periods of declining water levels or when the waterlevel change is not constant, unsaturated-zone storage is not at a steady state (inflow less than or greater than outflow; fig. 5).

This assessment is consistent with the groundwaterstorage change at station MN04 (fig. 4) for October 18, 2010, that was low in relation to the water level when compared with the groundwater-storage change at station MN04 for 


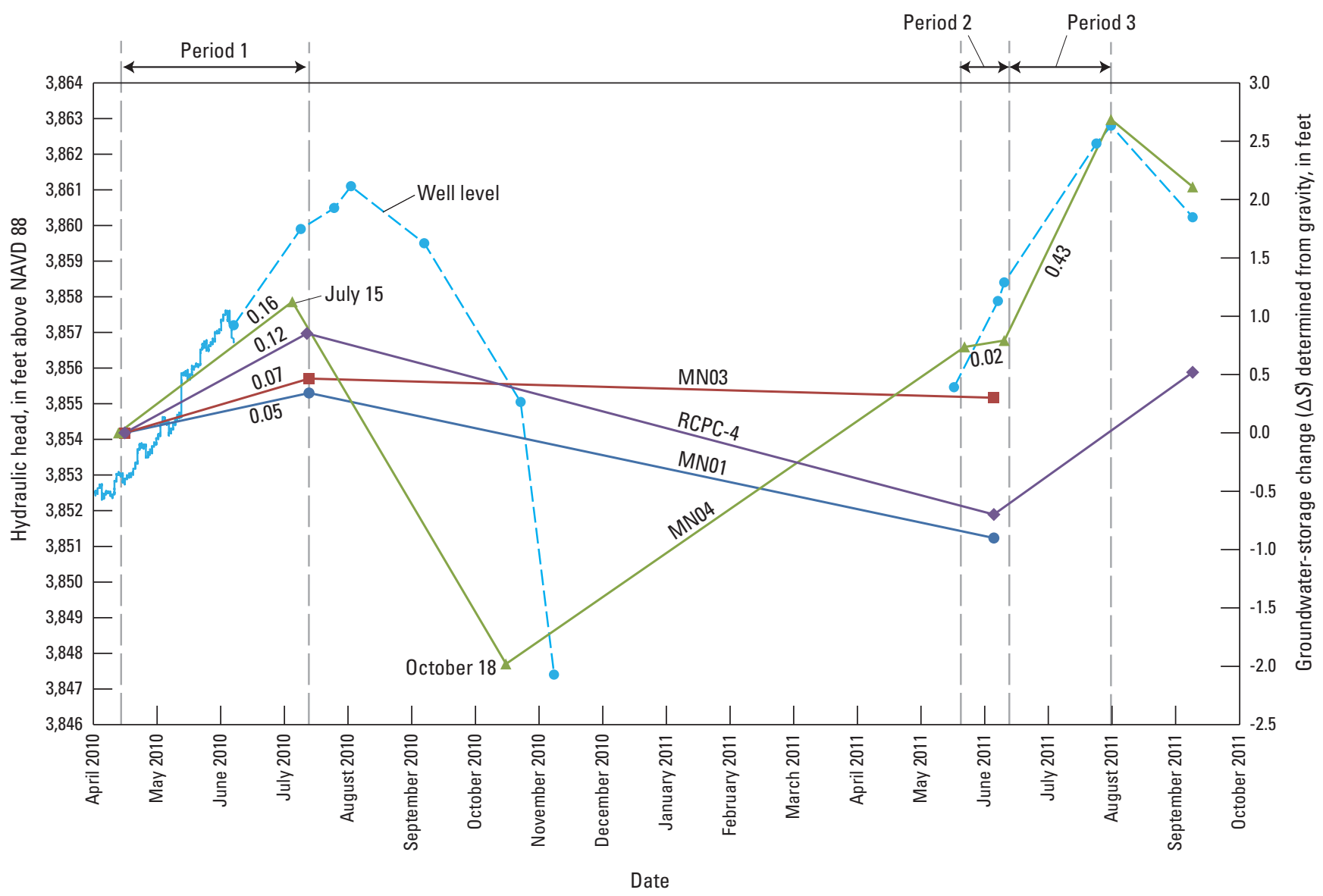

EXPLANATION

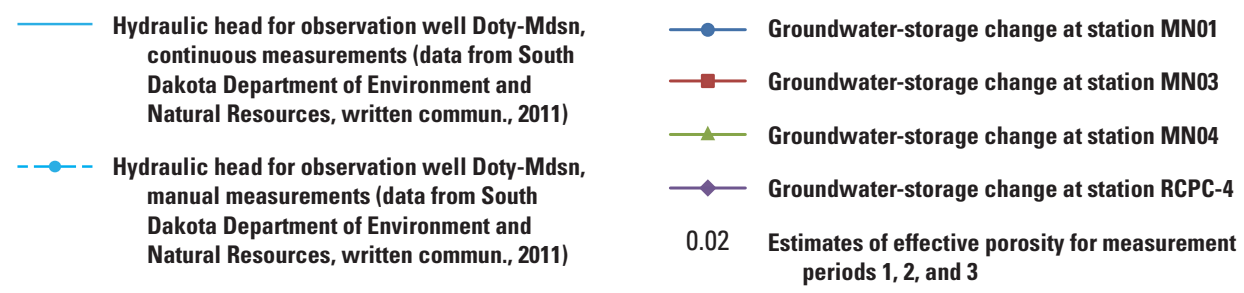

Figure 4. Groundwater-storage change $(\Delta S)$ determined from gravity data for group 2 stations (MN01, MN03, MN04, and RCPC-4) in the Doty focus area plotted with the hydrograph for observation well Doty-Mdsn (PE-95C).

July 15,2010 , in relation to the water level at that time. Therefore, the groundwater-storage change for October 18, 2010, probably resulted from a decrease in unsaturated-zone storage prior to this measurement.

Therefore, periods of steady increase in groundwater levels were assumed to provide the best estimates of effective porosity. Specifically, periods 1, 2, and 3 (fig. 4) are assumed to provide the best estimates of effective porosity as calculated by equation 8 because of the steady increase in water level (hydraulic head) for well Doty-Mdsn during these periods. Period 2 may provide the best estimate because it occurs well after the onset of spring recharge and before recharge begins to subside, which is presumably the most likely time for steady-state conditions in the unsaturated zone. The estimated effective porosity values for the Madison aquifer beneath station MN04 are $0.16,0.02$, and 0.43 for periods 1 , 2 , and 3, respectively. Errors in effective porosity estimations were evaluated using the maximum uncertainty in $g$ values determined from field surveys with a minimum error no less than the published $\pm 5 \mu \mathrm{Gal}$ accuracy of the $\mathrm{CG}-5$ gravimeter and an uncertainty of $\pm 0.5 \mathrm{ft}$ for water-level observations for corresponding relative-gravity surveys. These errors represent the maximum possible uncertainty in measurements and were propagated using the techniques described by Taylor (1982). On the basis of this error analysis, possible ranges for these effective porosity estimates are 0.10 to 0.24 , greater than $(>) 0$ to 0.16 , and 0.27 to 0.59 for periods 1,2 , and 3 , respectively. Differences in these estimates indicate vertical heterogeneity 


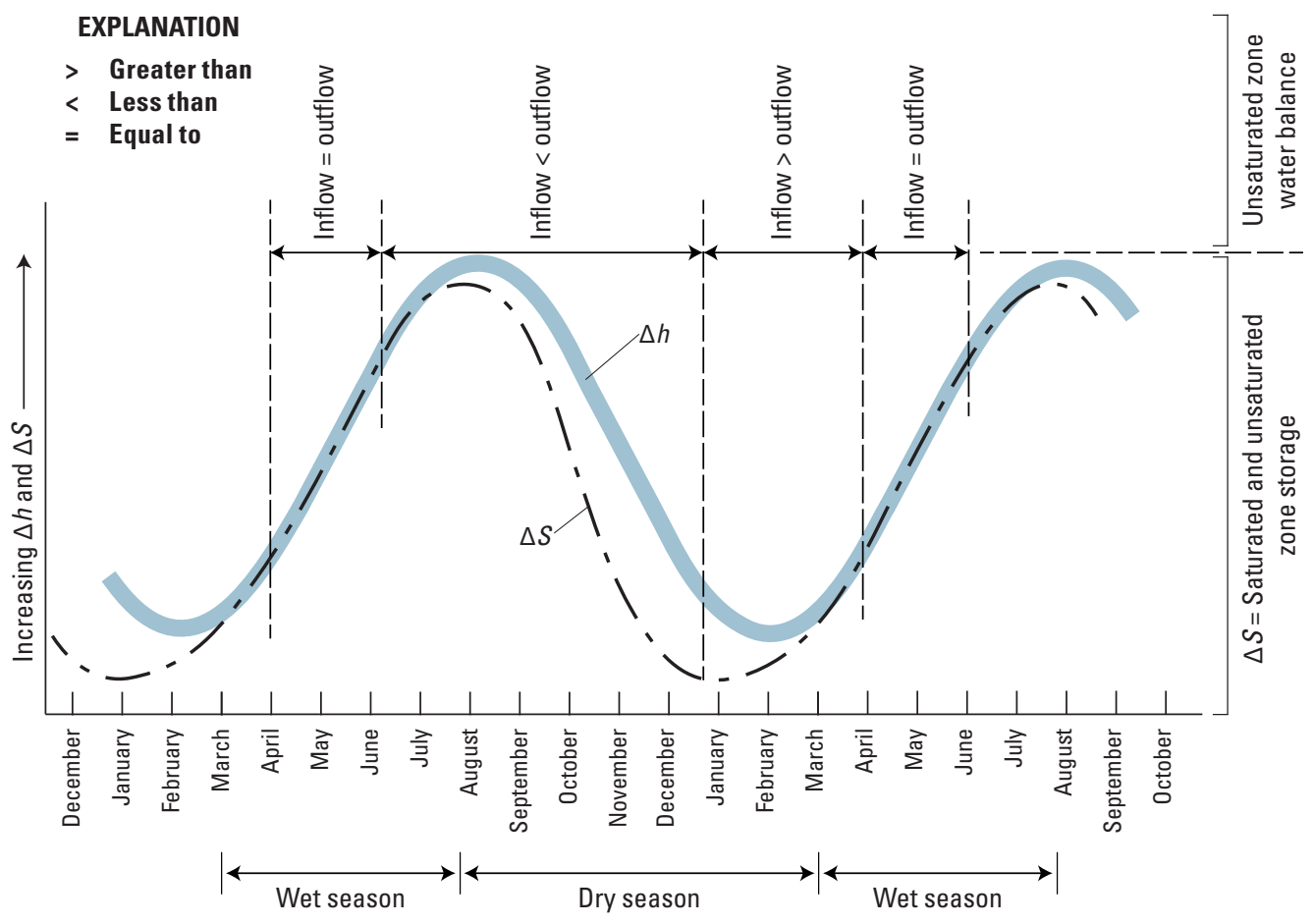

Figure 5. Conceptual plot of change in water-table altitude $(\Delta h)$ and groundwater-storage change $(\Delta S)$ with divisions where the balance of inflow to outflow in the unsaturated zone changes.

because the water-table changes for these three periods occurred at different altitudes. Period 1 also was assumed to provide useful estimates of effective porosity for gravity stations MN01, MN03, and RCPC-4 (fig. 4) with values from $>0$ to $0.11,>0$ to 0.14 , and 0.06 to 0.18 , respectively. These values are complementary to the estimate of average effective porosity from Greene (1993) of 0.35 for the Madison aquifer. The estimate in Greene (1993) was made using resistivity logs from Madison aquifer wells over a 600 -ft thick section of the Madison aquifer.

Average effective porosity values estimated for the Madison aquifer beneath station MN04 for the three periods correspond to three overlapping vertical sections (fig. 6). The altitude of these vertical sections at station MN04 were determined using potentiometric surfaces estimated by Strobel and others (2000) to determine water levels at station MN04 that correspond to water levels at well Doty-Mdsn for the three periods. Estimates represent average effective porosity values for each vertical section, but heterogeneity could exist within sections. If estimates from these three periods are combined, then additional information related to the vertical heterogeneity of effective porosity is obtained. Combining the three periods results in new information for four subsections derived from the original three overlapping sections (fig. 6; sections a-d). If the estimate of 0.02 for period 2 (section $b$ ) is combined with the estimate of 0.16 for period 1 (average for sections a-c), then the average effective porosity of sections a and $c$ is 0.27 based on an average calculation weighted by the vertical length of each subsection. Additional measurements corresponding to other overlapping vertical sections would provide a basis on which to determine the effective porosity

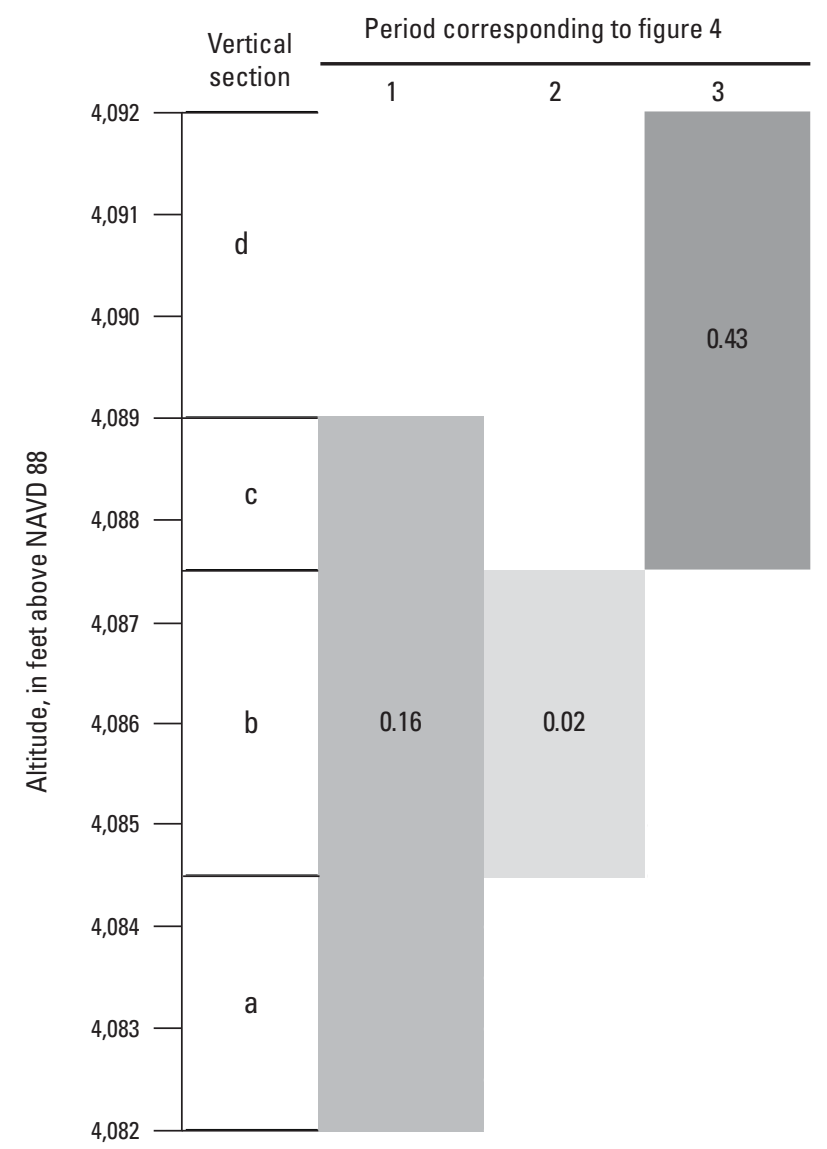

Figure 6. Effective porosity estimates for Madison aquifer beneath station MNO4 for vertical sections a-d determined for three different time periods. 
for additional vertical subsections at this location, possibly isolating zones of very high porosity that might be interpreted as solution openings in the Madison aquifer.

For group 1 gravity stations (fig. 2), a large decrease in groundwater storage occurred during period 1 , a time during which the hydraulic head in well Doty-Mdsn was rising (fig. 7). Although the groundwater-storage decline is opposite to what was expected for the spring recharge period, data for all five of these gravity stations were consistent, indicating that measurements probably were not in error. This storage decline might be explained by possible outflow of perched groundwater or the downgradient cascading of groundwater from cave to cave as described in the "Hydrogeology of the Study Area" section. As an example, an event similar to this occurred in the southern Black Hills in 1996 in Wind
Cave, which is contained in the Madison Limestone. During this event, a cave lake, which previously was dry for many years, appeared in one of the passages within a timeframe of 1 month and presumably was the result of the rapid emptying of perched water from a proximal cave opening at a higher altitude (Long and others, 2012). Because of its sudden appearance, the lake was named What the Hell Lake. Another example is illustrated by the water-level record for a lake in Brooks Cave located west of Rapid City and contained in the Madison Limestone; the water level rose during spring and remained relatively constant at an altitude of about $3,464 \mathrm{ft}$ until declining during each fall season from 1988 until 1992 (Driscoll and others, 2000; fig. 8). This altitude is interpreted as the altitude at which water from this cave lake spilled out into the surrounding aquifer because of an outlet that existed

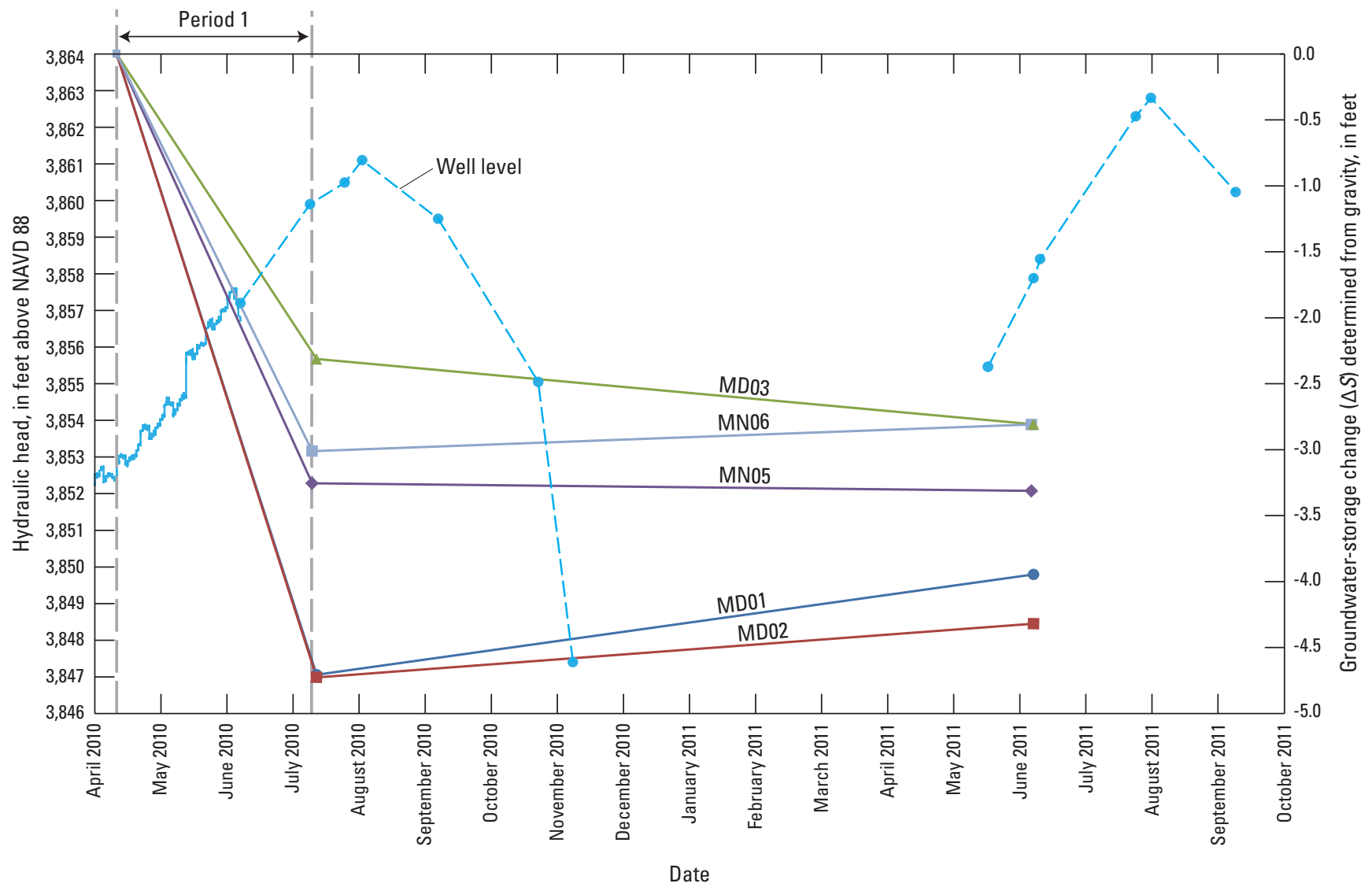

\section{EXPLANATION}

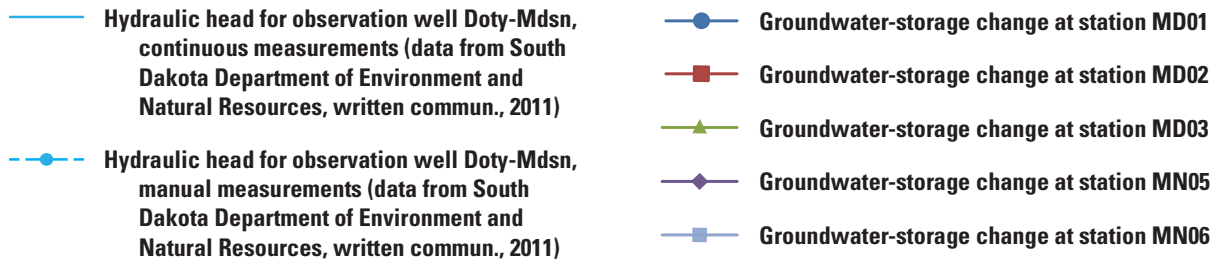

Figure 7. Groundwater-storage change $(\Delta S)$ determined from gravity data for group 1 stations (MD01, MD02, MD03, MN05, and MN06) in the Doty focus area plotted with the hydrograph for observation well Doty-Mdsn (PE-95C). 
at this altitude. Also, water probably seeped out continuously, possibly through clay sediments that filled other outlets, which resulted in water-level declines during the fall seasons when recharge declined. After 1992, this annual cycle changed and is characterized by multiple rapid declines annually, possibly resulting from periodic outflows through outlets that were intermittently filled with clay sediments or other debris. Increases in precipitation rates during the early 1990s (Driscoll and others, 2000) might have resulted in changes to the hydraulics controlling outflow from this lake.

Rapid emptying of groundwater from a cave or network of connected caves could result in a total groundwater-storage change that is dominated by the storage decline in these caves. For example, if the water level in a cave declined by $10 \mathrm{ft}$, then $\Delta S$ at this location would be $-10 \mathrm{ft}$ because the effective porosity is 1.0 inside the cave, whereas if the water table increased by $10 \mathrm{ft}$ in an adjacent area where the effective porosity is 0.1 , then $\Delta S$ would be only $+1 \mathrm{ft}$. An event such as this could explain the large decline in total groundwater storage during period 1 for group 1 gravity stations (figs. 2 and 7).

\section{Limestone Plateau Focus Area}

Measurements of $g$ at absolute-gravity station O27, which is at the highest altitude of any of the gravity stations in this study, were made annually in the summers of 2009-11 and the spring of 2012 using the A-10 gravimeter. The change in groundwater-storage determined from gravity during these periods was similar to the change in the water level in well Chyn-Xing-Mdsn (fig. 9). Little groundwater-storage or water-level change occurred between September 2009 and July 2010 (fig. 9). Following the same procedure as in the Doty focus area for periods of increasing groundwater levels (hydraulic head), the effective porosity was estimated by using equation 8 for the period between July 2010 and June 2011, which resulted in an estimated effective porosity ranging from 0.01 to 0.03 in the Madison aquifer beneath gravity station $\mathrm{O} 27$ for the vertical section in which the water level increased during that period. This estimate assumes that groundwaterstorage change in the unsaturated zone was small. Karst aquifers commonly are highly heterogeneous, and much higher values of effective porosity are expected to occur elsewhere in the Limestone Plateau area.

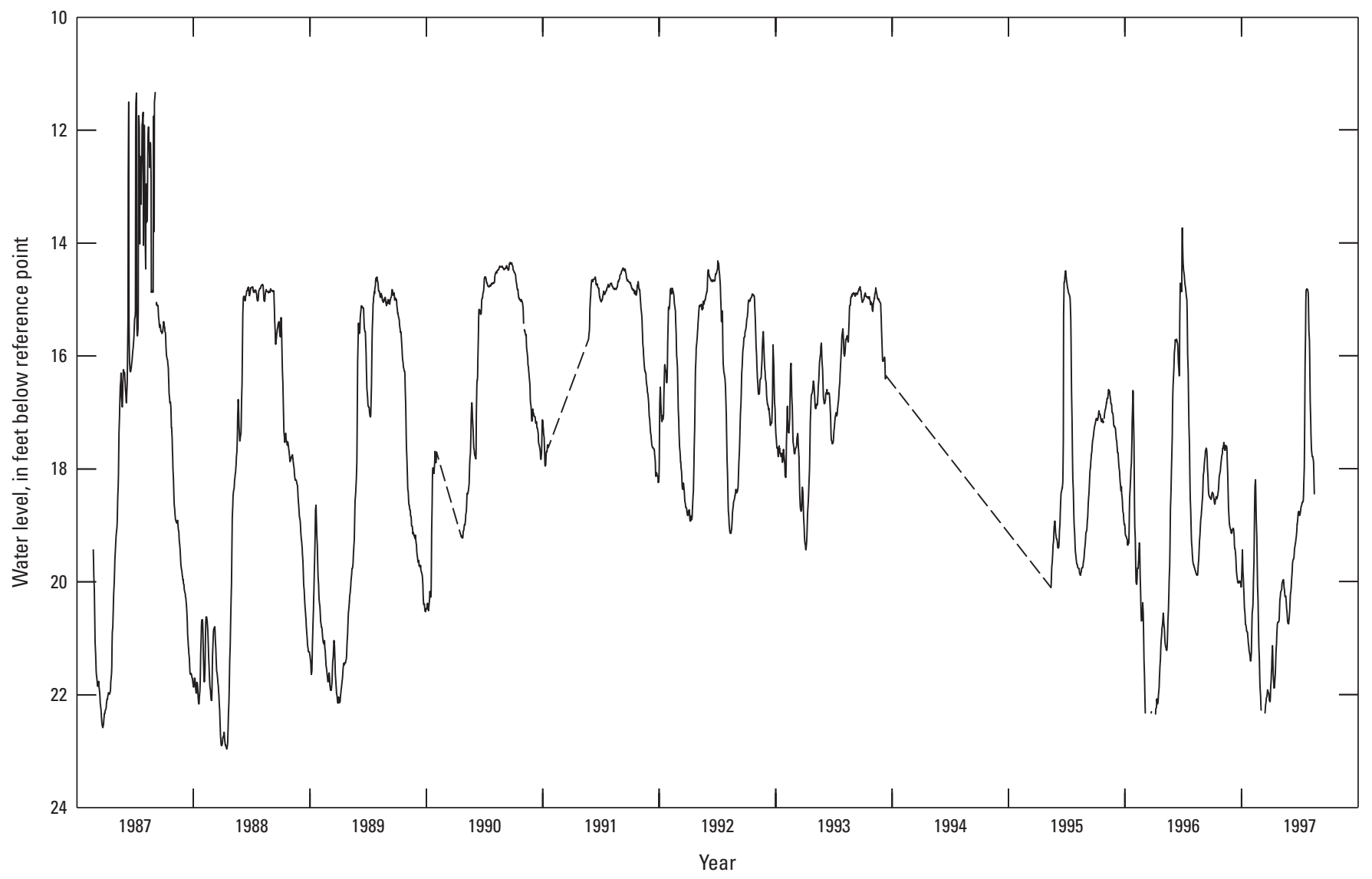

Figure 8. Water-level hydrograph for lake in Brooks Cave from 1988 to 1998 (modified from Driscoll and others, 2000). 


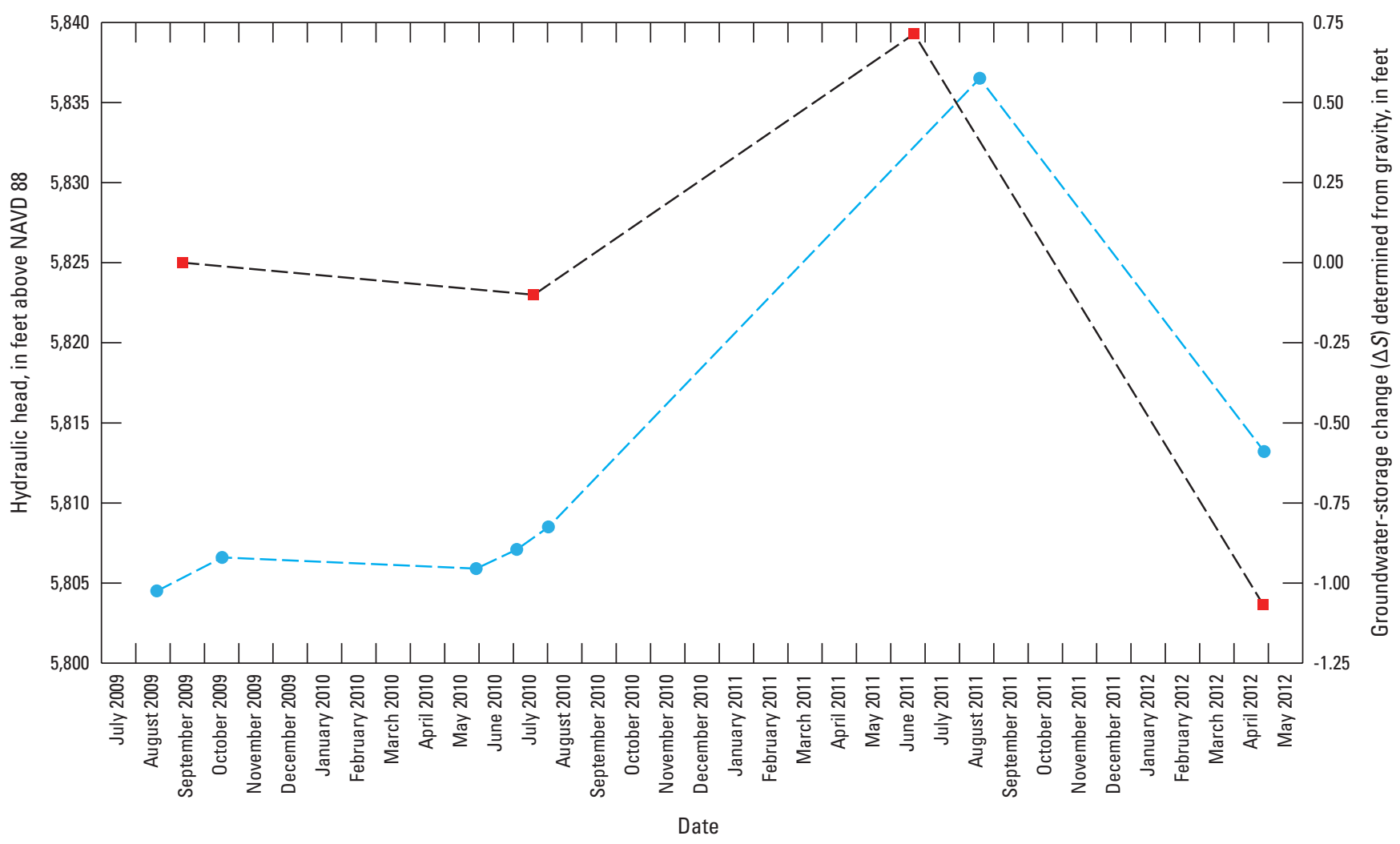

EXPLANATION

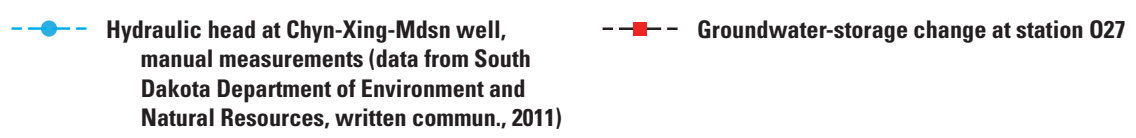

Figure 9. Groundwater-storage change $(\Delta S)$ determined from gravity data for station 027 plotted with the hydrograph for observation well Chyn-Xing-Mdsn (LA-95B).

\section{Limitations of Microgravity Methods}

Microgravity methods have advantages over traditional groundwater-monitoring techniques because measurements are made without the need for invasive and time consuming measures to drill a well into the formation in question. Microgravity also allows these storage-change measurements to be made at nearly any location over the aquifer. However, the ability to measure groundwater-storage change indirectly with microgravity does have limitations. As described in the "Methods for Determining Groundwater-Storage Change and Effective Porosity" section of this report, the microgravity methods used in this investigation do not supply information about the altitude beneath the gravity station where groundwaterstorage change is occurring; microgravity data only provide estimates of total groundwater-storage change at a particular location. Additionally, microgravity data alone do not allow for estimation of aquifer properties. In order to make estimates of effective porosity, microgravity data must be paired with other hydrologic data such as hydraulic-head measurements in observation wells. As described in the "Spring Canyon Focus
Area" section of this report, the corresponding hydraulic-head measurements may not reflect the nature of the groundwater flow beneath a gravity station and upgradient from the observation well. This is especially true in areas where karst topography exists.

Another factor that limits the certainty of gravity measurements is the stability of absolute-gravity reference stations, which are assumed to be in areas of little to no groundwater-storage change. In this study, $g$ was measured at absolute-gravity station VLR2 three times during the study to track the stability of the reference station. These measurements showed a linear increase in $g$ at station VLR2. This change is likely a result of station VLR2 being located on a ridge top, which makes the measurement sensitive to the nearby region downhill from the station altitude. Therefore, changes in surface-water volume in the adjacent valleys may lead to changes in $g$ at station VLR2. This change was addressed by linearly interpolating between the two measurements at station VLR2 for each relative-gravity connecting survey. The third measurement was made in the spring of 2012 after the data analysis was complete and therefore was not included in 
the final data; however, the measurement confirmed the linear increase in gravity at station VLR2. A new absolute-gravity station on the Harney Peak Granite (WR1; fig. 1) has been established for future gravity studies in the Black Hills region to address the apparent instability at station VLR2. The new station (WR1) is located in an area that is geologically similar to the area for absolute-gravity station HP2, and therefore, little change in $g$ from groundwater-storage fluctuations is expected at station WR1. The A-10 absolute gravimeter will be used to verify that groundwater-storage change at this station is zero or negligible.

\section{Summary}

Microgravity methods were used to estimate groundwater-storage change in the karstic Madison aquifer in the Black Hills of South Dakota for a study conducted by the U.S. Geological Survey in cooperation with West Dakota Water Development District, South Dakota Department of Environment and Natural Resources, and Lawrence County. The microgravity data obtained from 2009 to 2012 were used to investigate groundwater-storage changes and effective porosity in unconfined areas of the Madison aquifer. Groundwater-storage change determined from microgravity measurements is expressed as the change in the vertical height of water with no rock present. Time-lapse microgravity surveys that used portable high-sensitivity absolute and relative gravimeters indicated temporal-gravity changes as a result of changing groundwater mass. These extremely precise measurements of gravity required characterization and removal of internal instrumental and external environmental effects on gravity from the raw data. The corrected data allowed groundwaterstorage volume to be quantified with an accuracy of about plus or minus 0.5 foot of water per unit area of aquifer. Quantification of groundwater-storage change, coupled with water-level data from observation wells located near three focus areas, also was used to calculate the effective porosity at specific altitudes directly beneath gravity stations. These estimates demonstrate the utility of absolute- and relative-gravity measurements in groundwater-storage monitoring applications.

Gravity stations were established on bedrock outcrops in three separate focus areas for this study. The first area, the Spring Canyon focus area, is located south of Rapid City with one gravity station on the rim of Spring Canyon near the area where Spring Creek sinks into the Madison aquifer. A U.S. Geological Survey streamgage located upstream from this location allowed for measurements of streamflow over the recharge area. The second area, the Doty focus area, is located on outcrops of the Madison Limestone and Minnelusa Formation to the northwest of Rapid City, and consists of nine gravity stations. These stations were located on the land surface above the water table of the unconfined Madison aquifer, in an area that included part of the unconfined Minnelusa aquifer. It was assumed that most of the measured groundwater-storage change occurred at or near the water table and therefore primarily in the Madison aquifer. The third area, the Limestone Plateau focus area, consists of a single gravity station located in the northwestern Black Hills on an outcrop of the Madison Limestone. This study area is located at the highest altitude of the three study areas, and recharge likely occurs as a result of direct infiltration of precipitation. An absolute-gravity station, used to tie relative-gravity survey data together, was established on a relatively impermeable bedrock outcrop to minimize groundwater-storage change at the reference location.

Data from the three focus areas allowed for interpretation of groundwater-storage characteristics using microgravity measurements. Results indicated that rapid groundwaterstorage change occurred in an unconfined area near a sinking stream in Spring Canyon as a result of aquifer recharge from the stream. This rapid groundwater-storage change likely was a result of groundwater movement through caverns, conduits, and fractures, which are common in karst aquifers. Estimates of effective porosity were not possible at this location because the response to recharge at the observation well was different than that of the Spring Canyon gravity station. Groundwaterstorage change at the Spring Canyon site between April 7, 2010, and September 25, 2011, varied by a total of 3.4 feet of water per unit area of aquifer.

Spatially and temporally separated microgravity data for the Doty focus area indicated horizontal and vertical heterogeneity of effective porosity. Water-level measurements at an observation well and gravity measurements at four gravity stations in the southeastern part of the Doty area (group 2) were used to estimate effective porosity values ranging from greater than 0 to 0.18 . Repeat measurements at one station in this group (MN04) during periods when unsaturated-zone storage was assumed to be zero allowed for estimations of effective porosity in three vertical sections at different altitudes. These measurements were combined to further isolate vertical differences of effective porosity, which ranged from greater than 0 to 0.59 . A decrease in groundwater storage determined by microgravity measurements during the spring recharge period for five upgradient stations in the northwestern part of the Doty focus area (group 1) indicated the possibility of a rapid release and downgradient cascading of perched groundwater. Evidence for similar phenomena was documented for Wind and Brooks Caves (both of which are contained in the Madison Limestone) in the Black Hills.

Absolute-gravity measurements in the Limestone Plateau focus area confirmed the relation between water levels in observation wells and groundwater-storage change. Comparison of groundwater-storage change determined from gravity measurements with water levels in a nearby observation well resulted in an effective porosity estimate ranging from greater than 0 to 0.03 for the Madison aquifer beneath the gravity station.

The microgravity method offers advantages over traditional groundwater-monitoring techniques because it is noninvasive and allows for measurements at nearly any location over the unconfined aquifer. Microgravity measurements 
are particularly informative when combined with additional hydrologic data, such as hydraulic-head measurements in observation wells, which in certain cases allows for estimation of effective porosity in the underlying aquifer. The stability of absolute-gravity stations is an important factor limiting the quality of microgravity data, and therefore, it is essential to choose a suitable site for an absolute-gravity reference station and to monitor the stability of the accelerative force of gravity at that location.

\section{References Cited}

Blainey, J.B., Ferre, P.A., and Cordova, J.T., 2007, Assessing the likely value of gravity and drawdown measurements to constrain estimates of hydraulic conductivity and specific yield during unconfined aquifer testing: Water Resources Research, v. 43, W12408, 9 p.

Bowles, C.G., and Braddock, W.A., 1963, Solution breccias of the Minnelusa Formation in the Black Hills, South Dakota and Wyoming in Short papers in geology and hydrology, Articles 60-121: U.S. Geological Survey Professional Paper 475-C, p. C91-C95.

Carter, J.M., Driscoll, D.G., and Sawyer, J.F., 2003, Groundwater resources in the Black Hills area, South Dakota: U.S. Geological Survey Water-Resources Investigations Report 03-4049, 36 p. (Also available at $h t t p: / / p u b s . u s g s$. gov/wri/wri034049/.)

Christiansen, L., Lund, S., Andersen, O.B., Binning, P.J., Rosbjerg, D., and Bauer-Gottwein, P., 2011, Measuring gravity change caused by water storage variations-Performance assessment under controlled conditions: Journal of Hydrology, v. 402, p. 60-70.

Cunningham, W.L., and Schalk, C.W., 2011, Groundwater technical procedures of the U.S. Geological Survey: U.S. Geological Survey Techniques and Methods 1-A1, $151 \mathrm{p}$.

Damiata, B.N., and Lee, Tien-Chang, 2006, Simulated gravitational response to hydraulic testing of unconfined aquifers: Journal of Hydrology, v. 318, p. 248-359.

Driscoll, D.G., Bradford, W.L., and Moran, M.J., 2000, Selected hydrologic data, through water year 1998, Black Hills Hydrology Study, South Dakota: U.S. Geological Survey Open-File Report 00-70, 284 p. (Also available at http://pubs.usgs.gov/of/2000/ofr0070/.)

Greene, E.A., 1993, Hydraulic properties of the Madison aquifer system in the western Rapid City area, South Dakota: U.S. Geological Survey Water-Resources Investigations Report 93-4008, 56 p. (Also available at $h t t p: / / p u b s . w a t e r$. usgs.gov/wri934008/.)
Greene, E.A., Shapiro, A.M., and Carter, J.M., 1998, Hydrologic characterization of the Minnelusa and Madison aquifers near Spearfish, South Dakota: U.S. Geological Survey Water-Resources Investigations Report 98-4156, 64 p. (Also available at http://pubs.er.usgs.gov/publication/ wri984156.)

Gries, J.P., and Martin, J.E., 1981, Composite outcrop section of the Paleozoic and Mesozoic strata in the Black Hills and surrounding areas, in Rich, F.J., ed., Geology of the Black Hills, South Dakota and Wyoming (2d ed.), Field Trip Guidebooks, Geological Society of America Rocky Mountain Section 1981 Annual Meeting: Rapid City, S. Dak., American Geological Institute, p. 261-292.

Heath, Ralph C., 2004, Basic ground-water hydrology: U.S. Geological Survey Water-Supply Paper 2220, 91 p. (Also available at http://pubs.er.usgs.gov/publication/wsp2220.)

Hortness, J.E., and Driscoll, D.G., 1998, Streamflow losses in the Black Hills of western South Dakota: U.S. Geological Survey Water-Resources Investigations Report 98-4116, 99 p. (Also available at http://pubs.usgs.gov/wri/ wri984116/.)

Jacob, T., Bayer, R., Chery, J., and Le Moigne, N., 2010, Time-lapse microgravity surveys reveal water storage heterogeneity of a karst aquifer: Journal of Geophysical Research B-Solid Earth, v. 115, no. 6, 18 p.

Long, A.J., Ohms, M.J., and McKaskey, J.D.R.G., 2012, Groundwater flow, quality (2007-10), and mixing in the Wind Cave National Park area, South Dakota: U.S. Geological Survey Scientific Investigations Report 2011-5235, 50 p. (Also available at http://pubs.usgs.gov/ sir/2011/5235/.)

Long, A.J., and Putnam, L.D., 2002, Flow-system analysis of the Madison and Minnelusa aquifers in the Rapid City area, South Dakota - Conceptual model: U.S. Geological Survey Water-Resources Investigations Report 02-4185, 100 p., 3 pls. (Also available at http://pubs.usgs.gov/wri/ wri024185/wri024185.html.)

Montgomery, D.C., and Runger, G.C., 2007, Applied statistics and probability for engineers (4th ed.): Hoboken, N.J., John Wiley and Sons, Inc., 768 p.

Pool, D.R., and Anderson, M.T., 2008, Ground-water storage change and land subsidence in Tucson Basin and Avra Valley, southeastern Arizona, 1998-2002: U.S. Geological Survey Scientific Investigations Report 2007-5275, 34 p. (Also available at $h t t p: / / p u b s . u s g s . g o v /$ sir/2007/5275/.)

Pool, D.R., and Eychaner, J.H., 1995, Measurements of aquifer-storage change and specific yield using gravity surveys: Ground Water, v. 33, no. 3, p. 425-432. 
Pool, D.R., and Schmidt, Werner, 1997, Measurement of ground-water storage change and specific yield using the temporal-gravity method near Rillito Creek, Tucson, Arizona: U.S. Geological Survey Water-Resources Investigations Report 97-4125, 30 p. (Also available at $h t t p: / /$ az.water.usgs.gov/pubs/WRIR97-4125intro.html.)

Putnam, L.D., and Long, A.J., 2007, Analysis of ground-water flow in the Madison aquifer using fluorescent dyes injected in Spring Creek and Rapid Creek near Rapid City, South Dakota, 2003-04: U.S. Geological Survey Scientific Investigations Report 2007-5137, 27 p. (Also available at http:// pubs.usgs.gov/sir/2007/5137/.)

Redden, J.A., and DeWitt, Ed, 2008, Maps showing geology, structure, and geophysics of the central Black Hills, South Dakota: U.S. Geological Survey Scientific Investigations Map 2777, 44 p. pamphlet, 2 sheets. (Also available at http://pubs.usgs.gov/sim/2777/.)

Strobel, M.L., Jarrell, G.J., Sawyer, J.F., Schleicher, J.R., and Fahrenbach, M.D., 1999, Distribution of hydrogeologic units in the Black Hills area, South Dakota: U.S. Geological Survey Hydrologic Investigations Atlas HA-743, 3 sheets. (Also available at http://pubs.usgs.gov/ha/ha743/.)

Strobel, M.L., Galloway, J.M., Hamade, G.R., and Jarrell, G.J., 2000, Potentiometric surface of the Madison aquifer in the Black Hills area, South Dakota: U.S. Geological Survey Hydrologic Atlas HA-745-D, 2 sheets, scale 1:100,000. (Also available at $h t t p: / / p u b s . u s g s . g o v / h a / h a 745 d /$.)

Taylor, J.R., 1982, An introduction to error analysis-The study of uncertainties in physical measurements: Sausalito, California, University Science Books, 327 p.

Telford, W.M., Geldart, L.P., and Sheriff, R.E., 1990, Applied geophysics ( $2 \mathrm{~d}$ ed.): Cambridge, U.K., Cambridge University Press, $770 \mathrm{p}$.

Torge, Wolfgang, 1989, Gravimetry: Berlin, Walter de Gruyter and Co., $465 \mathrm{p}$.

U.S. Geological Survey, 2012, USGS water data for South Dakota: National Water Information System, digital data, accessed June 1, 2012, at http://waterdata.usgs.gov/sd/ nwis/. 


\section{Appendix}

Relative-gravity data collected continuously at the U.S. Geological Survey (USGS) South Dakota Water Science Center in Rapid City, South Dakota, on September 19, 2011, indicated that small, nonlinear internal drift (a combined effect of spring hysteresis and small discontinuities in the measurement function), with an amplitude ranging from approximately 3 to 25 microgals $(\mu \mathrm{Gal})$, is still present in temporal relativegravity data after removal of the theoretically modeled Earth tides; that is, the nonlinear drift must be removed from the data. The magnitude of drift varies from day-to-day depending on handling and transport conditions and can only be determined empirically. An example of this effect is illustrated in figure 1-1. In this figure, continuous 117 -second interval relative-gravity data are averaged into an aggregate of 18-minute intervals, which reveals residual perturbations with amplitudes of about $3 \mu \mathrm{Gal}$ ( 0.003 milligals). The averaged 18 -minute interval data resembles the time interval between field survey measurements and establishes a baseline for the nonlinear stationary drift. A sixth-order polynomial was fit to and plotted with these data and may be used to remove the nonlinear drift from this dataset (Montgomery and Runger, 2007).

All of the field data collected during a survey were used collectively to estimate the nonlinear drift. After the averaged relative-gravity value for each station and each occupation was determined, a single polynomial curve was fit to the timeseries data for each station. This curve represents a combination of internal instrument drift and variable atmospheric loading during a survey. To ensure a polynomial fit that is constrained by observed data, the order of the polynomial must be smaller than the number of data points. For this study, the order of the polynomial was limited to 60 percent or less of the number of data points, with a maximum polynomial order of six. The order of the polynomial fit for a survey loop is determined from:

$$
O_{\mathrm{p}} \leq 0.6 * n
$$

and

$$
1 \leq O_{\mathrm{p}} \leq 6
$$

where

$$
\begin{gathered}
O_{\mathrm{p}} \\
n \quad \text { is the order of the polynomial, and } \\
\text { is the number of averaged relative-gravity } \\
\text { measurements. }
\end{gathered}
$$

For example, a survey loop conducted on June 9, 2011, consisted of a base station and three relative-gravity stations. The survey loop was repeated three times for a total of 12 data points for curve fitting. The averaged relative-gravity values at each gravity station (MN04, MN05, MN06, and MD01) are plotted in figure 1-2. Although the 12 measurements obtained during this survey allow for the use of a sixth-order polynomial, an acceptable fit was achieved using a fifth-order polynomial, which is shown on figure 1-2. The curve fit for each station was allowed to have a different y-intercept of the polynomial to account for different accelerative force of gravity $(g)$ values between stations. Figure 1-2 (all stations) shows relative-gravity data for all of the gravity stations in the survey loop shifted to the base station y-intercept and plotted with the fitted fifth-order polynomial, which clearly shows the character of the nonlinear drift throughout the survey period. It is important to note that the amplitude of the nonlinear drift is larger in the field survey compared to the survey conducted at the USGS South Dakota Water Science Center because the gravimeter was handled during the field survey, thus contributing the added amplitude of nonlinear transport drift to the fitted function.

The fitted nonlinear drift function was removed from the relative-gravity data by interpolating the amount of drift based on the time of the individual relative-gravity measurements. The drift corrected measurement was obtained by subtracting the interpolated value from the field measurement. The result is a linear function of relative-gravity measurements. The deviation from the mean of the drift corrected relative-gravity data determines the uncertainty in the final gravity values for each survey. 


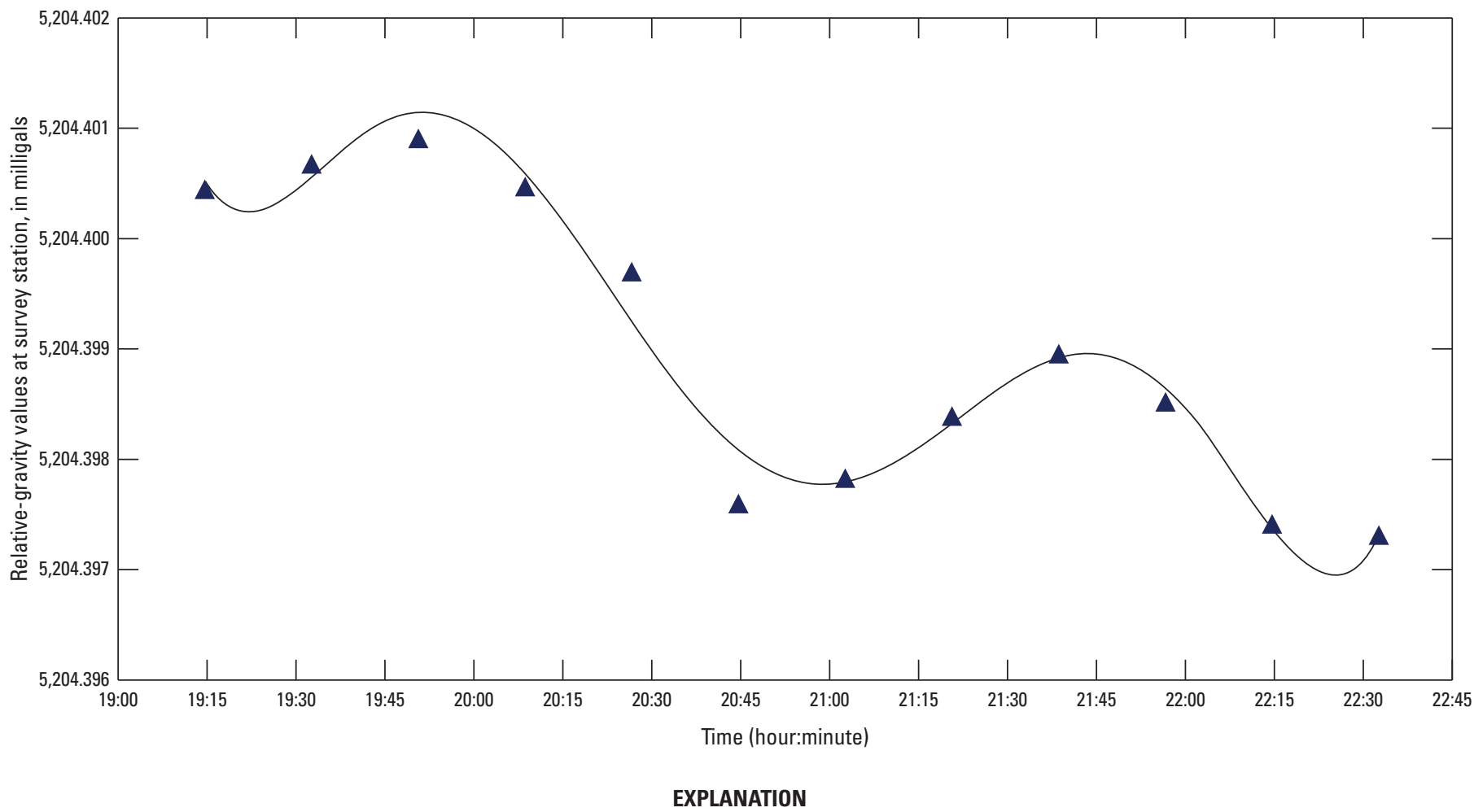

- Relative-gravity measurements at the U.S. Geological

Survey South Dakota Water Science Center

Sixth-order polynomial best-fit line

Figure 1-1. Relative-gravity measurements made at the U.S. Geological Survey South Dakota Water Science Center in Rapid City, South Dakota, on September 19, 2011, plotted with a fitted sixth-order polynomial. 


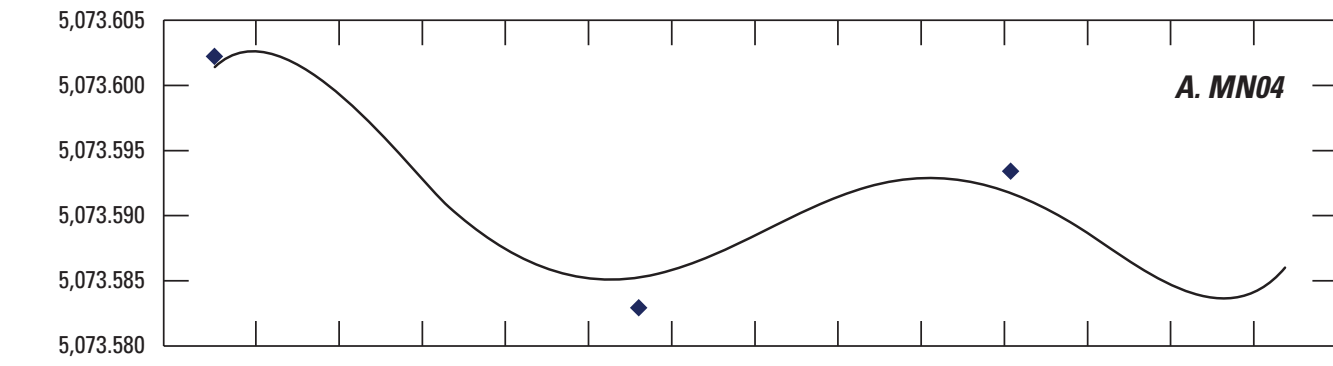

EXPLANATION

Fifth-order polynomial best-fit line

Relative-gravity measurement at:

- Station MN04
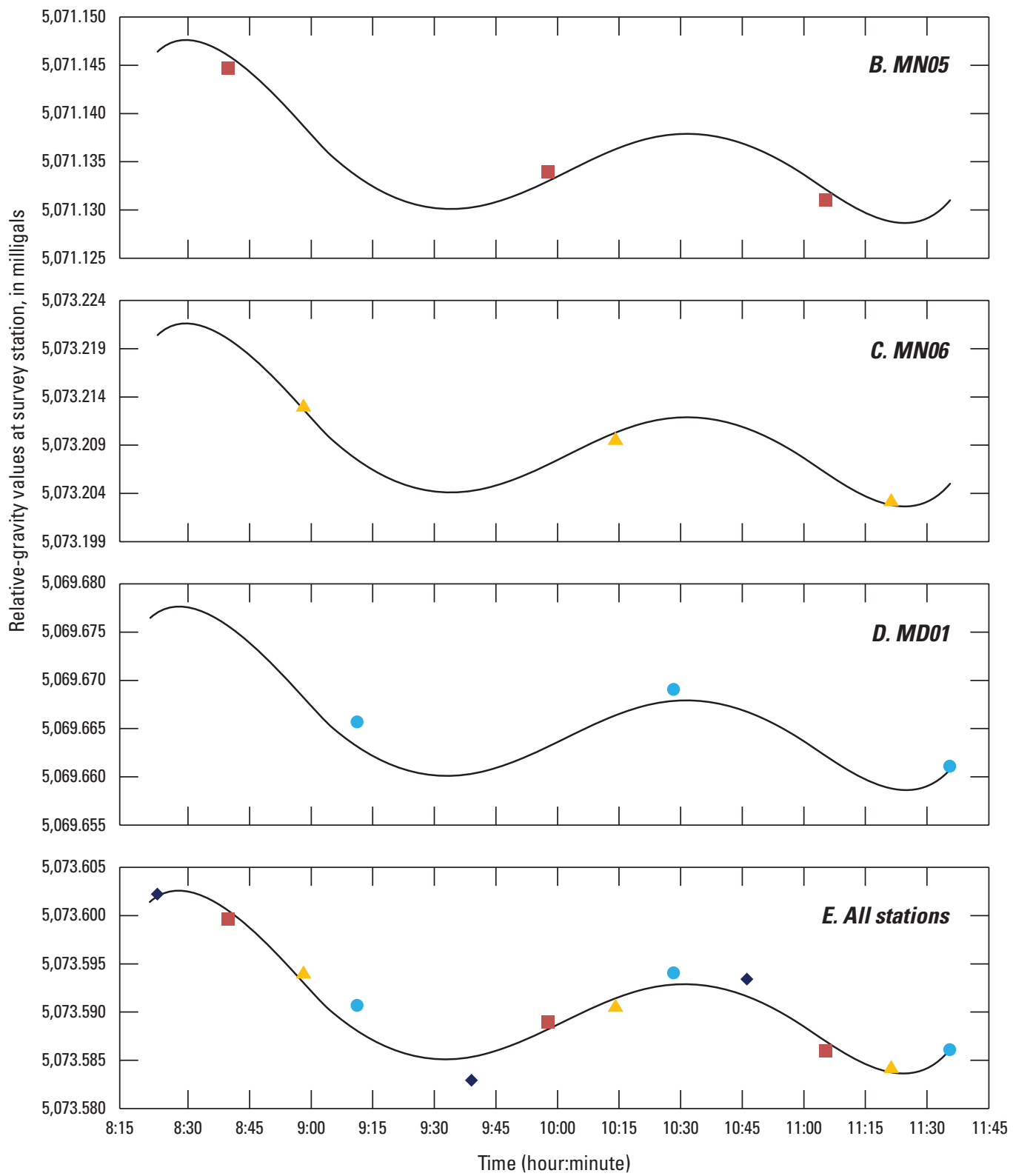

Figure 1-2. Relative-gravity measurements for a survey conducted on June 9, 2011, at stations MN04, MN05, MN06, and MD01 $(A-D$, respectively) plotted with a fitted fifth-order polynomial. Plot $E$ shows all gravity measurements on June 9,2011 , shifted to the base station (MNO4) intercept and plotted with the fitted fifth-order polynomial. 
Publishing support provided by the:

Denver, Lafayette, and Rolla Publishing Service Centers

For more information concerning this publication, contact: Director, USGS South Dakota Water Science Center 1608 Mt. View Road, Rapid City, SD 57702

(605) $394-3200$

Or visit the South Dakota Water Science Center Web site at: http://sd.water.usgs.gov/ 


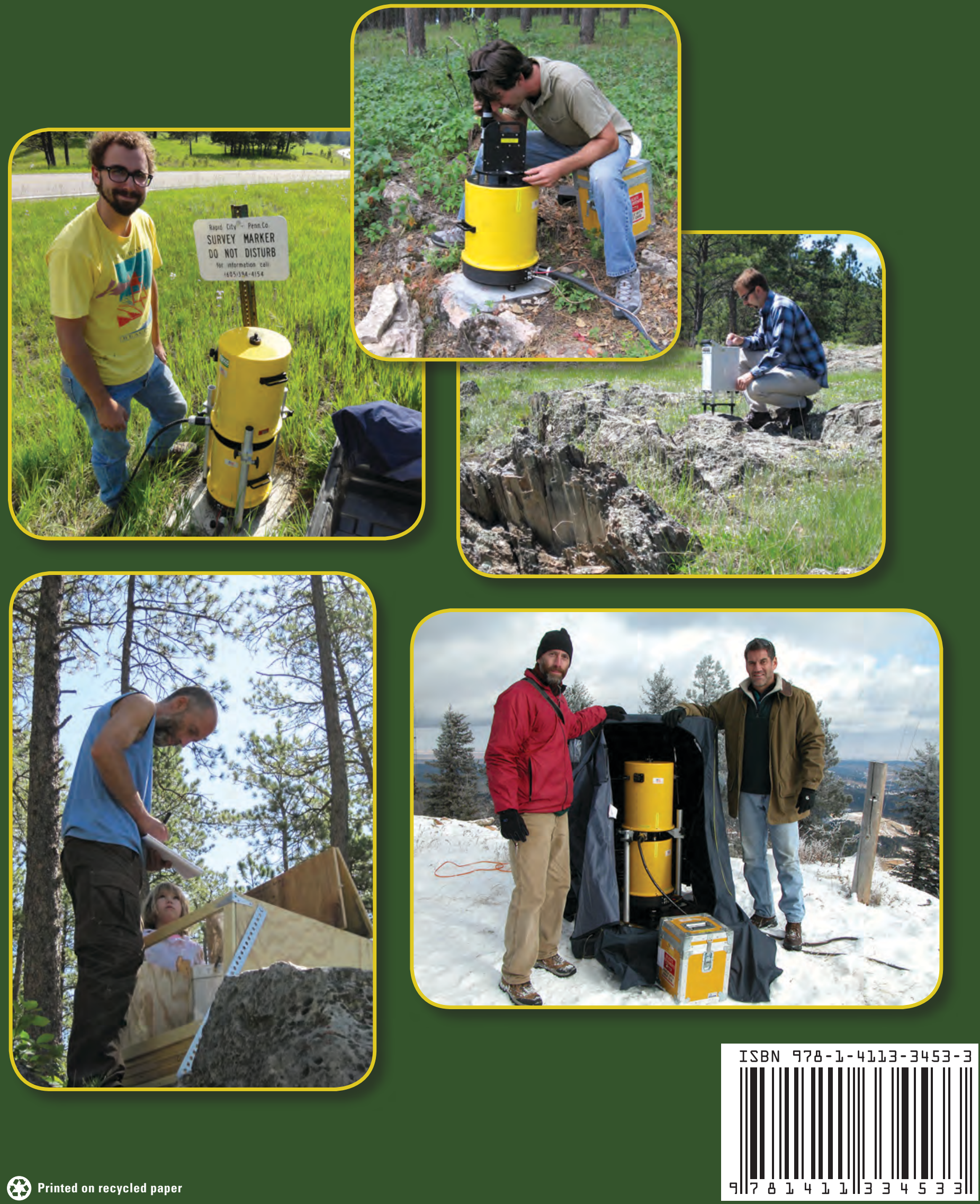

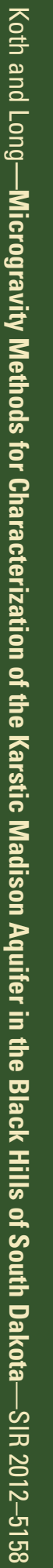

